\title{
MOBILITAS SOSIAL NELAYAN PASCA SEDIMENTASI DAERAH ALIRAN SUNGAI (DAS) \\ (Studi Kasus: Desa Klaces, Kecamatan Kampung Laut, Kabupaten Cilacap, Provinsi Jawa Tengah)
}

\author{
Septi Agusning Kuwandari*) dan Arif Satria \\ Departemen Sains Komunikasi dan Pengembangan Masyarakat, Fakultas Ekologi Manusia, IPB \\ *) Email: s_agus_ning_k@yahoo.com
}

\begin{abstract}
The interaction between human and nature will cause many ecological impacts, such as declining environment quality. The relationship between inland and sea can not be separated each other. The inland damaged will affect coastal areas. Sedimentation in Watershed (DAS) make ecological changes, it's accordingly. It can greatly affect the socio-economic conditions of coastal communities. This situation leads the communities to develop strategies adaptation which finally change stratification system and social mobility.
\end{abstract}

Keywords: coastal, sedimentation, social mobility, strategies adaptation, Watershed (DAS)

\section{PENDAHULUAN}

\section{Latar Belakang}

Negara Kesatuan Republik Indonesia (NKRI) dikenal sebagai negara maritim dengan wilayah lautan yang luas dan mengandung sumberdaya laut yang melimpah. Berdasarkan data BPS (2011), Indonesia terdiri atas 17.504 pulau dengan panjang garis pantai $95.181 \mathrm{~km}^{2}$. Kelestarian ekosistem dan ketersediaan sumberdaya pesisir sangat memengaruhi kesejahteraan masyarakat yang hidup di sepanjang pesisir laut Indonesia, khususnya masyarakat yang bekerja sebagai nelayan. Terjadinya kerusakan ekologi di wilayah pesisir merupakan hal yang patut untuk menjadi sorotan. Menurut Dahuri dkk (1996), ada dua jenis kerusakan lingkungan berdasarkan sumber kejadiannya, yaitu yang berlangsung di dalam wilayah pesisir dan ada yang berasal dari luar wilayah pesisir. Kerusakan lingkungan yang berlangsung di dalam wilayah pesisir adalah pencemaran yang berasal dari limbah yang dibuang oleh berbagai kegiatan pembangunan yang terdapat di dalam wilayah pesisir itu sendiri. Kerusakan lingkungan yang berasal dari luar sistem wilayah pesisir adalah pencemaran yang berupa kiriman dari berbagai kegiatan pembangunan di wilayah lahan atas (hulu).

Sedimentasi Daerah Aliran Sungai (DAS) adalah salah satu permasalahan utama yang mengakibatkan perubahan ekologi, sosial, dan ekonomi di wilayah pesisir. Menurut Yunus dan Dharmawan (2005), DAS merupakan satu kesatuan ekosistem yang utuh antara hulu, tengah, dan hilir. Apabila DAS hulu rusak maka hilir akan menanggung akibatnya. Begitu pula apabila DAS tengah dan hilir rusak maka yang menanggung akibatnya adalah tetap hilir.

Proses penurunan kualitas dan perubahan ekosistem pesisir yang terjadi secara alami maupun akibat aktivitas manusia mengakibatkan perubahan ekologi yang berdampak pada sosial-ekonomi nelayan. Hal inilah yang dialami oleh nelayan di sekitar Segara Anakan, yaitu Desa Klaces, Kampung Laut. Segara Anakan merupakan muara beberapa sungai yang selama bertahun-tahun telah mengalami sedimentasi. Sedimentasi di Segara Anakan berasal dari DAS Citanduy ${ }^{1}$, Cibeureum, Cikonde, dan Ujung Alang. Berdasarkan data KPSKSA Kabupaten Cilacap (2009), sedimentasi yang bermuara di Segara Anakan mengakibatkan penurunan luas perairan dari 6.898 hektar pada Tahun 1890 menjadi 784,74 hektar pada Tahun 2007.

Perubahan ekosistem laut menjadi ekosistem darat tersebut memengaruhi aktivitas nelayan di wilayah pesisir. Berbagai upaya dilakukan nelayan dalam menghadapi perubahan yang terjadi untuk dapat bertahan hidup melalui strategi adaptasi. Strategi adaptasi yang dilakukan nelayan pada akhirnya akan merubah posisinya dalam masyarakat sehingga terjadilah mobilitas sosial nelayan.

\footnotetext{
${ }^{1}$ Sungai Citanduy merupakan penyumbang terbesar sedimen di Segara Anakan, yaitu $5 \mathrm{~m}^{2} /$ tahun (KPSKSA Kabupaten Cilacap 2009).
} 


\section{Masalah Penelitian}

Berdasarkan latar belakang yang telah dikemukakan di atas, maka rumusan masalah penelitian ini adalah sebagai berikut:

1. Bagaimana strategi adaptasi nelayan pasca sedimentasi Daerah Aliran Sungai (DAS)?

2. Bagaimana strategi adaptasi nelayan memengaruhi mobilitas sosial nelayan pasca sedimentasi Daerah Aliran Sungai (DAS)?

\section{Tujuan Penelitian}

Adapun tujuan penelitian ini adalah untuk mengetahui, mengidentifikasi, dan menganalisis:

1. Strategi adaptasi nelayan pasca sedimentasi Daerah Aliran Sungai (DAS).

2. Pengaruh strategi adaptasi nelayan terhadap mobilitas sosial nelayan pasca sedimentasi Daerah Aliran Sungai (DAS).

\section{Kegunaan Penelitian}

Penelitian ini diharapkan dapat bermanfaat bagi beberapa pihak, yaitu:

1. Bagi akademisi, penelitian ini diharapkan dapat menambah khasanah ilmu pengetahuan, serta menjadi bahan referensi dan kajian untuk penelitian selanjutnya.

2. Bagi pemerintah, penelitian ini diharapkan dapat memberikan masukan bagi para pengambil kebijakan dalam mengelola dan memanfaatkan sumberdaya pesisir yang berkelanjutan. Selain itu, diharapkan agar pemerintah dapat menyusun strategi pemberdayaan yang tepat, sesuai dengan kondisi masyarakat.

3. Bagi masyarakat, penelitian ini diharapkan mampu menambah informasi dan wawasan masyarakat mengenai strategi adaptasi nelayan dan pengaruhnya terhadap mobilitas sosial nelayan pasca sedimentasi Daerah Aliran Sungai (DAS).

\section{PENDEKATAN TEORITIS}

\section{Tinjauan Pustaka}

\section{Perubahan Ekologi Pesisir Akibat Sedimentasi Daerah} Aliran Sungai (DAS)

Menurut Dharmawan (2007), perubahan ekologi adalah dampak yang tidak dapat dielakkan dari interaksi antara manusia dan alam yang berlangsung dalam konteks pertukaran (exchange). KPSKSA Kabupaten Cilacap (2009) menyatakan bahwa ada beberapa ekosistem pesisir yang terkena dampak perubahan ekologi, yaitu laguna, estuaria, mangrove, dan delta. Salah satu penyebab perubahan ekologi yang terjadi di wilayah pesisir adalah sedimentasi Daerah Aliran Sungai (DAS).

Menurut Suripin (2002), Daerah Aliran Sungai (DAS) adalah wilayah yang dibatasi oleh batas alam, seperti punggung bukit-bukit atau gunung, maupun batas buatan, seperti jalan atau tanggul, dimana air hujan yang turun di wilayah tersebut memberi kontribusi aliran ke titik kontrol (outlet). Ekosistem DAS merupakan bagian penting karena memiliki fungsi perlindungan terhadap DAS. Fungsi suatu DAS merupakan fungsi gabungan seluruh faktor pada DAS, yaitu vegetasi, bentuk wilayah (topografi), tanah, dan manusia.

Terjadinya sedimentasi DAS sangat erat kaitannya dengan terjadinya erosi di sepanjang DAS. Menurut Arsyad (2010), erosi adalah peristiwa pindah atau terkikisnya tanah atau bagian-bagian tanah dari satu tempat ke tempat lain oleh air atau angin. Iswandi (2003) menyatakan bahwa sedimen adalah hasil proses erosi, baik berupa erosi permukaan, erosi parit, atau jenis erosi tanah lainnya. Sedimen inilah yang mengakibatkan terjadinya sedimentasi yang merupakan hasil interaksi manusia dan alam di DAS.

Sedimentasi yang terjadi di Daerah Aliran Sungai (DAS) mengakibatkan perubahan ekologi di wilayah pesisir. Terjadinya perubahan-perubahan ekologi di wilayah pesisir sangat memengaruhi kondisi sosial-ekonomi masyarakat pesisir.

\section{Masyarakat Pesisir}

Menurut Undang-undang Nomor 27 Tahun 2007 tentang Pengelolaan Wilayah Pesisir dan Pulau-pulau Kecil, wilayah pesisir adalah daerah peralihan antara ekosistem darat dan laut yang dipengaruhi oleh perubahan di darat dan laut. Eksistensi suatu wilayah erat kaitannya dengan keberadaan masyarakat yang hidup di wilayah tersebut. Satria (2009) mendefinisikan masyarakat pesisir sebagai sekumpulan masyarakat yang hidup bersama-sama mendiami wilayah pesisir, membentuk, dan memiliki kebudayaan yang khas terkait dengan ketergantungannya pada pemanfaatan sumberdaya pesisir. Menurut Satria (2002), berbeda dengan sosiologi pedesaan yang berbasis pada society, sosiologi masyarakat pesisir lebih berbasis pada sumberdaya, sehingga kajian-kajian sosiologi masyarakat pesisir bersumber pada aktivitas masyarakat yang terkait dengan sumberdaya perikanan. Nelayan merupakan bagian dari masyarakat pesisir yang memiliki ketergantungan yang tinggi terhadap sumberdaya perikanan.

Ditjen Perikanan (2000) dalam Satria (2002) mendefinisikan nelayan sebagai orang yang secara aktif melakukan pekerjaan dalam operasi penangkapan ikan/binatang air lainnya/tanaman air. Sementara orang yang hanya melakukan pekerjaan seperti membuat jaring, mengangkut alat-alat perlengkapan ke dalam perahu/kapal, tidak dimasukkan sebagai nelayan. Namun, ahli mesin dan juru masak yang bekerja di atas kapal penangkap dimasukkan sebagai nelayan, meskipun mereka tidak secara langsung melakukan penangkapan.

\section{Strategi Adaptasi}

Menurut Hansen (1979) dalam Saharuddin (2007), adaptasi merupakan konsep yang merujuk pada konsep 
proses penyesuaian pada perubahan keadaan. Masyarakat melakukan adaptasi dengan tujuan untuk mengoptimalkan kesempatan hidup. Ada beragam strategi adaptasi yang dapat dilakukan oleh masyarakat dalam menghadapi perubahan ekologi, diantaranya adalah:

1. Jejaring/hubungan sosial dengan memanfaatkan ikatan kekerabatan serta pertukaran timbal balik dalam pemberian rasa aman dan perlindungan (Carner 1984).

2. Pola nafkah ganda, yaitu menganekaragamkan pekerjaan meskipun dengan upah yang rendah (Carner 1984). Menurut Satria (2009), salah satu strategi yang dapat dilakukan untuk memutus rantai kemiskinan nelayan adalah strategi nafkah ganda agar nelayan tidak hanya menggantungkan hidup pada tangkapan ikan saja.

3. Memobilisasi peran istri dan anak-anak untuk ikut mencari nafkah keluarga (Kusnadi 2000).

4. Migrasi ke daerah lain (biasanya migrasi desa-kota) sebagai alternatif terakhir apabila sudah tidak terdapat lagi pilihan sumber nafkah di desanya (Carner 1984).

5. Alih mata pencaharian dengan mengganti pekerjaan utama (Patriana 2011).

6. Menggandaikan atau menjual barang-barang rumah tangga yang dimiliki, serta melakukan konversi pekerjaan bagi nelayan (Kusnadi 2000).

\section{Stratifikasi Sosial}

Soekanto (1990) menyatakan bahwa stratifikasi sosial berarti pembedaan populasi berdasarkan kelas secara hirarki. Ada tiga bentuk stratifikasi sosial (Sorokin 1962), yaitu:

1. Stratifikasi berdasarkan ekonomi (economically stratified), yaitu jika dalam suatu masyarakat terdapat perbedaan atau ketidaksetaraan status ekonomi.

2. Stratifikasi berdasarkan politik (politically stratified), yaitu jika terdapat rangking sosial berdasarkan otoritas, prestise, kehormatan, dan gelar, atau jika ada pihak yang mengatur (the rulers) dan yang diatur (the ruled).

3. Stratifikasi berdasarkan pekerjaan (occupationally stratified), yaitu jika masyarakat terdiferensiasi ke dalam berbagai pekerjaan dan beberapa di antara pekerjaan itu lebih tinggi statusnya dibandingkan pekerjaan lain.

Soekanto (1990) menjelaskan bahwa gejala stratifikasi sosial adalah suatu tipe diferensiasi dan atau ketidaksamaan sosial yang menunjuk pada adanya suatu hirarki sistematis dalam penilaian atas beragam tingkatan pada sejumlah kedudukan beserta peranan yang merupakan unsur-unsur baku dalam sistem stratifikasi sosial. Kedudukan dan peranan tersebut dijelaskan sebagai berikut:

1. Kedudukan adalah tempat atau posisi seseorang dalam suatu kelompok sosial. Masyarakat pada umumnya mengenal dua macam kedudukan, yaitu kedudukan yang diperoleh karena kelahiran (ascribed status) dan kedudukan yang dicapai oleh seseorang dengan usaha-usaha yang disengaja (achieved status). Selain itu, seringkali dibedakan satu kedudukan lagi, yaitu kedudukan yang diberikan (assigned status).

2. Peranan (role) merupakan aspek dinamis kedudukan (status). Apabila seseorang melaksanakan hak dan kewajibannya sesuai dengan kedudukannya maka ia telah menjalani suatu peranan.

Berdasarkan dua unsur stratifikasi sosial tersebut, Soekanto (1990) membedakan dua jenis sistem stratifikasi sosial, yaitu sistem terbuka (sistem status yang berlaku adalah ascribed status) dan sistem tertutup (sistem status yang berlaku adalah achieved status).

\section{Mobilitas Sosial}

Soekanto (1990) mendefinisikan gerak sosial sebagai suatu gerak dalam struktur sosial, yaitu pola-pola tertentu yang mengatur organisasi suatu kelompok sosial. Struktur sosial mencakup sifat-sifat hubungan antara individu dalam kelompok dan hubungan antar individu dengan kelompoknya.

Sorokin (1959) menyebutkan ada dua gerak sosial yang mendasar, yaitu gerak sosial horizontal dimana terjadi peralihan status individu atau kelompok dari suatu kelompok sosial ke kelompok sosial lainnya yang sederajat, dan gerak sosial vertikal dimana peralihan individu atau kelompok dari suatu kedudukan sosial ke kedudukan lainnya yang tidak sederajat. Sesuai dengan arahnya, gerak sosial vertikal secara khusus dapat dibedakan menjadi dua, yaitu:

1. Gerak sosial vertikal naik (social climbing), berupa: (i) masuknya individu-individu yang mempunyai kedudukan rendah ke dalam kedudukan yang lebih tinggi yang telah ada sebelumnya; atau (ii) pembentukan suatu kelompok baru yang kemudian ditempatkan pada derajat yang lebih tinggi dari kedudukan individu-individu pembentuk kelompok itu.

2. Gerak sosial vertikal turun (social sinking), berupa: (i) turunnya kedudukan individu ke kedudukan yang lebih rendah derajatnya; atau (ii) turunnya derajat sekelompok individu yang dapat berupa suatu disintegrasi dalam kelompok sebagai kesatuan.

Sistem pelapisan sosial masyarakat membawa konsekuensi terhadap peluang mobilitas sosial. Pada sistem pelapisan sosial tertutup, mobilitas sosial vertikal hampir tidak ada, karena kedudukan seseorang telah ditentukan sejak ia lahir. Sementara itu, pada sistem pelapisan sosial terbuka, kedudukan apa yang hendak dicapai, semuanya terserah pada usaha dan kemampuan individu (Soekanto 1990). 
Menurut Satria (2000) berdasarkan status attainment model (Hess dkk 1985), terdapat dua jenis mobilitas sosial, yaitu mobilitas sosial intra-generasi dan mobilitas sosial antar-generasi. Mobilitas sosial intra-generasi mengacu pada perbedaan status yang dicapai nelayan sejak pertama kali bekerja dan status saat ini. Sementara mobilitas antar-generasi mengacu pada perbedaan status yang dicapai seseorang dengan status orang tuanya.

Setiap masyarakat memiliki sistem stratifikasi sosial yang berbeda-beda dengan ciri khas masing-masing. Ada tiga pendekatan untuk mempelajari stratifikasi sosial suatu masyarakat (Zanden 1990), yaitu:

1. Pendekatan objektif, yaitu menggunakan ukuran objektif berupa variabel yang mudah diukur secara statistik (kuantitatif) seperti pendidikan, pekerjaan, atau pendapatan.

2. Pendekatan subjektif, yaitu munculnya pelapisan sosial dalam masyarakat tidak diukur dengan kriteria-kriteria yang objektif, melainkan dipilih menurut kesadaran subjektif warga itu sendiri. Kelas dilihat sebagai kategori sosial dan disusun dengan meminta para responden survai untuk menilai status sendiri dengan jalan menempatkan diri pada skala kelas tertentu.

3. Pendekatan reputasional, yaitu pelapisan sosial disusun dengan cara subjek penelitian diminta menilai status orang lain dengan jalan menempatkan orang lain tersebut ke dalam skala tertentu.

Satria (2001) menggambarkan stratifikasi sosial masyarakat ke dalam enam tingkatan yang kemudian dapat digunakan untuk mengetahui stratifikasi sosial dan mobilitas sosial dalam masyarakat. Piramida tersebut tersaji pada Gambar 1 .

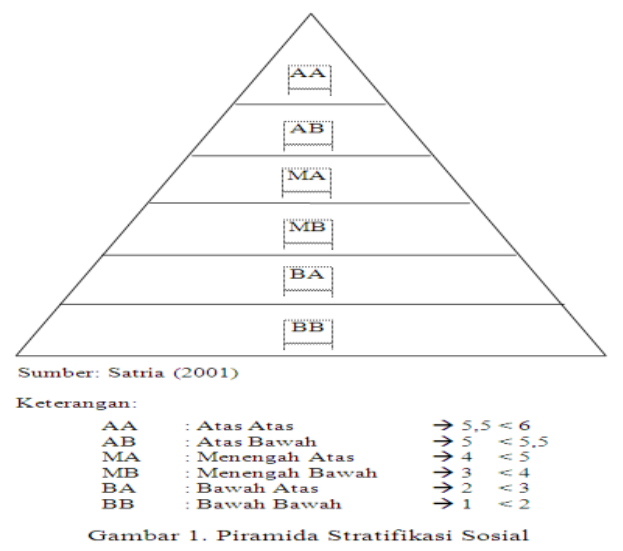

Posisi individu dalam masyarakat ditentukan berdasarkan hasil survai (pekerjaan) yang diolah dengan menggunakan rumus $\mathrm{x}=\frac{\sum(\mathrm{ab})}{n}$, dimana $\mathrm{x}$ merupakan lapisan stratifikasi pekerjaan, a merupakan jumlah responden yang memilih lapisan, b merupakan tingkatan lapisan, dan $\mathrm{n}$ adalah jumlah responden. ${ }^{2}$

\section{Kerangka Pemikiran}

Desa Klaces merupakan salah satu desa di Kecamatan Kampung Laut yang mengalami sedimentasi DAS. Sedimentasi DAS yang bermuara di Segara Anakan sebagai hilir dari beberapa sungai mengakibatkan berbagai bentuk kerusakan ekologi wilayah pesisir meliputi perubahan ekosistem laguna, estuaria, mangrove, dan delta. Perubahan pada ekosistemekosistem tersebut memunculkan dampak sosial dan ekonomi bagi nelayan yang mengharuskan nelayan untuk melakukan strategi adaptasi sebagai bentuk strategi bertahan hidup terhadap perubahan ekologi. Strategi adaptasi yang dilakukan nelayan dalam menghadapi perubahan ekologi pesisir mengakibatkan mobilitas sosial nelayan di Desa Klaces. Kondisi tersebut tersaji pada Gambar 2.

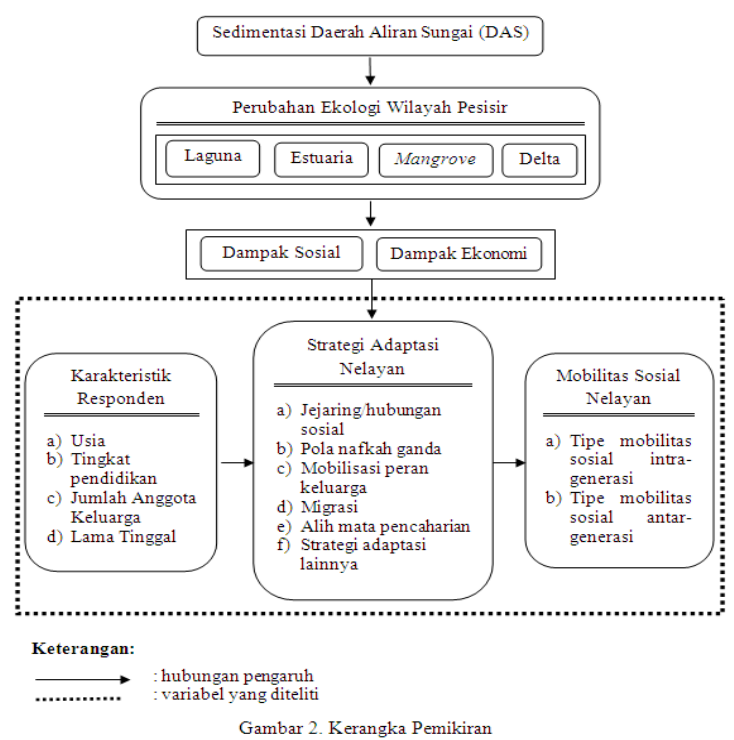

\section{Hipotesis Penelitian}

1. Terdapat hubungan nyata antara karakteristik responden dengan strategi adaptasi nelayan.

2. Terdapat hubungan nyata antara strategi adaptasi nelayan dengan mobilitas sosial nelayan.

\section{PENDEKATAN LAPANGAN}

\section{Metode Penelitian}

Penelitian ini menggunakan kombinasi pendekatan kuantitatif dan kualitatif. Pendekatan kuantitatif yang digunakan adalah metode survai dengan instrumen kuesioner. Sementara pendekatan kualitatif yang digunakan adalah metode triangulasi yang berguna untuk memperoleh kombinasi data yang akurat melalui uji

\footnotetext{
2 Dirumuskan berdasarkan batas-batas nilai setiap lapisan sosial menurut Satria (2001).
} 
keabsahan dengan uji silang tiga sumber data, yaitu hasil wawancara, observasi, dan studi literatur (Stake 2009). Strategi penelitian yang digunakan dalam penelitian ini adalah studi kasus yang merupakan strategi penelitian multi-metode, lazimnya memadukan antara observasi, wawancara, dan analisis dokumen (Sitorus 1998).

Penelitan ini merupakan penelitian deskriptif yang dimaksudkan untuk membuat penjelasan secara sistematis, faktual, dan akurat mengenai fakta-fakta dan sifat-sifat populasi atau daerah tertentu (Singarimbun 1989). Selain itu, penelitian ini juga menggunakan pendekatan untuk mengetahui dan mengidentifikasi stratifikasi sosial nelayan, yaitu pendekatan reputasional. Adapun alat bantu (peraga) untuk pendekatan ini adalah gambar piramida dengan pembeda warna untuk setiap tingkatan (digunakan untuk menjawab kuesioner mengenai mobilitas sosial nelayan).

\section{Lokasi dan Waktu Penelitian}

Penelitian ini dilakukan di Desa Klaces, Kecamatan Kampung Laut, Kabupaten Cilacap, Provinsi Jawa Tengah. Lokasi penelitian dipilih secara sengaja (purposive) dengan beberapa pertimbangan, yaitu: (1) Desa Klaces merupakan salah satu desa yang mendapatkan dampak sedimentasi Daerah Aliran Sungai (DAS), dan (2) Desa Klaces telah mengalami perubahan ekologi, sosial, dan ekonomi yang signifikan dari sedimentasi DAS sehingga memungkinkan terjadinya strategi adaptasi dan mobilitas sosial.

Waktu penelitian dilaksanakan pada bulan April-Mei 2012 dalam kurun waktu satu bulan, yang mencakup waktu selama peneliti mengumpulkan data di lapangan. Selama pengambilan data berlangsung, peneliti tinggal bersama subjek penelitian di lapangan dalam jangka waktu satu minggu. Hal ini dilakukan agar peneliti dapat mengetahui lokasi penelitian dengan baik dan juga terciptanya hubungan sosial yang dekat dengan subjek penelitian.

\section{Teknik Pemilihan Responden dan Informan}

Populasi dari penelitian ini adalah rumah tangga di Desa Klaces, Kecamatan Kampung Laut, Kabupaten Cilacap, Provinsi Jawa Tengah yang kepala keluarganya bekerja sebagai nelayan sebelum terjadinya sedimentasi Daerah Aliran Sungai (DAS) sebanyak 108 rumah tangga. Populasi didasarkan pada hasil sensus seluruh rumah tangga melalui informasi ketua RT setempat yang kemudian disesuaikan dengan data dari kantor kecamatan. Unit analisis dari penelitian ini adalah rumah tangga. Penentuan responden dilakukan dengan menggunakan teknik simple random sampling dengan jumlah responden sebanyak 30 kepala keluarga.

Jumlah informan dalam penelitian ini tidak dibatasi dengan tujuan untuk memperkaya informasi yang diperoleh. Pencarian informan dilakukan dengan menggunakan teknik bola salju (snowball sampling) yang memungkinkan perolehan data dari satu informan ke informan lainnya. Pencarian informan ini berhenti saat tambahan informan tidak lagi menghasilkan pengetahuan baru atau telah berada pada titik jenuh. Jumlah informan kunci penelitian ini setelah diterapkan teknik bola salju adalah 6 orang yang terdiri dari 1 orang Pegawai Kecamatan Kampung Laut dan 5 orang Perangkat Desa Klaces.

\section{Jenis dan Teknik Pengumpulan Data}

Jenis data yang dikumpulkan dalam penelitian ini adalah data primer dan data sekunder. Data primer merupakan data yang pengumpulannya dilakukan sendiri oleh peneliti. Data tersebut didapatkan langsung dari responden dan informan dengan menggunakan kuesioner dan wawancara mendalam, serta hasil observasi langsung peneliti.

Selain data primer, pengumpulan data dalam penelitian ini juga menggunakan data sekunder. Data sekunder merupakan data yang diperoleh secara tidak langsung oleh peneliti berupa literatur dan dokumen yang mendukung fakta-fakta di lapangan. Sumber data sekunder diperoleh dari Kantor Desa Klaces, Kantor Kecamatan Kampung Laut, Dinas Perikanan dan Kelautan Cilacap, serta buku, internet, jurnal-jurnal penelitian, skripsi, tesis, disertasi, dan laporan penelitian yang berkaitan dengan penelitian ini.

\section{Teknik Pengolahan dan Analisis Data}

Data kuantitatif adalah informasi mengenai hal-hal yang dapat diukur dan dapat dikuantifikasikan. Data kuantitatif dalam penelitian ini berguna untuk mengetahui dan mengidentifikasi, serta sebagai dasar untuk menganalisis karakteristik responden, strategi adaptasi nelayan, dan mobilitas sosial nelayan. Pengolahan data kuantitatif dalam penelitian ini mengacu pada langkah-langkah pengolahan data dari Effendi dkk (1989). Pertama, memasukkan data ke dalam kartu atau berkas (file) data. Kedua, membuat tabel frekuensi atau tabel silang. Ketiga, mengoreksi kesalahan-kesalahan yang ditemui setelah membaca tabel frekuensi atau tabel silang.

Setelah itu, data kuantitatif yang dikumpulkan akan dianalisis secara deskriptif untuk menggambarkan hubungan antara karakteristik responden dengan strategi adaptasi nelayan serta hubungan antara strategi adaptasi nelayan dengan mobilitas sosial nelayan. Teknik analisis data kualitatif dilakukan sejak awal pengumpulan data melalui wawancara mendalam dan observasi yang disajikan dalam bentuk catatan harian. Analisis data primer dan sekunder mengacu pada pendapat Miles dan Huberman (1992) dalam Sitorus (1998), dimana data diolah dengan melakukan tiga tahapan kegiatan dan dilakukan secara bersamaan, yaitu reduksi data, penyajian data, dan penarikan kesimpulan melalui verifikasi data. 


\section{GAMBARAN UMUM LOKASI DAN KARAKTERISTIK RESPONDEN PENELITIAN}

\section{Gambaran Umum Lokasi}

Desa Klaces merupakan salah satu desa di wilayah Kecamatan Kampung Laut, Kabupaten Cilacap, Provinsi Jawa Tengah. Secara geografis, desa ini berbatasan langsung dengan Pojok Tiga, Desa Ujung Gagak, dan Desa Panikel di sebelah utara, Klep Kali Mesigitsela dan Ujung Alang di sebelah timur, Pulau Nusakambangan dan Kelurahan Tambakreja di sebelah selatan, serta Sungai Citanduy, Desa Majingklak, Desa Pamotan, Kecamatan Kalipucang (Jawa Barat) di sebelah barat.

Desa ini merupakan desa pemekaran dari Desa Ujung Alang pada Tahun 2002 berdasarkan Keputusan Bupati Cilacap Nomor 06 Tahun 2002 tentang Penetapan Desa Persiapan Klaces Kecamatan Pembantu, Kampung Laut, Kabupaten Cilacap. Pemekaran dilakukan atas dasar pertimbangan perkembangan keadaan, pertimbangan teknis pemerintahan, pelaksanaan pembangunan, dan pelayanan kepada masyarakat.

Luas keseluruhan wilayah Desa Klaces adalah 19.302 hektar dengan luas darat 325 hektar dan laut 18.977 hektar, serta berada pada ketinggian dua meter di atas permukaan air laut. Secara administratif, Desa Klaces terbagi ke dalam 2 dusun, 2 rukun warga (RW), dan 11 rukun tetangga (RT). Jumlah penduduk Desa Klaces adalah 1.411 jiwa dengan rincian 697 jiwa laki-laki dan 714 jiwa perempuan. Penduduk Desa Klaces dikenal dengan sebutan Sundawa (Sunda Jawa) karena penduduknya sebagian besar beretnis jawa dan ada sebagian yang beretnis sunda (merupakan pendatang dari Jawa Barat).

\section{Karakteristik Responden}

Karakteristik responden adalah ciri-ciri yang melekat pada individu responden penelitian yang secara keseluruhan merupakan masyarakat di Desa Klaces, Kecamatan Kampung Laut, Kabupaten Cilacap, Provinsi Jawa Tengah. Karakteristik responden tersebut meliputi usia, tingkat pendidikan, jumlah anggota keluarga, dan lama tinggal. Responden penelitian ini cukup beragam pada setiap kategoti, yang secara umum disebabkan oleh: (1) untuk seluruh karakteristik responden, pemilihan responden dilakukan secara acak tanpa mengkhususkan pada kategori tertentu, serta (2) untuk karakteristik usia, jumlah anggota keluarga, dan lama tinggal, ada pengaruh penggantian responden utama dengan responden cadangan (saat pengambilan data, 5 responden tidak dapat ditemui karena sedang tidak berada di rumah sehingga digantikan oleh responden cadangan).

\section{Usia}

Usia adalah selisih antara tahun responden dilahirkan hingga ulang tahun terakhir. Berdasarkan hasil survai, usia responden bervariasi dari 20 tahun hingga 77 tahun. Usia responden dibagi menjadi dua kategori, yaitu muda
(20-46 tahun) dan tua (47-77 tahun). Jumlah responden usia muda sebanyak 16 orang $(53,3 \%)$ dan tua sebanyak 14 orang $(46,7 \%)$ dari keseluruhan responden. Hal tersebut menunjukkan bahwa jumlah dan persentase responden usia muda dan tua tidak jauh berbeda. Responden berusia muda sebagian besar merupakan pendatang, sedangkan responden berusia tua sebagian besar merupakan masyarakat asli yang sejak lahir hidup di Desa Klaces.

\section{Tingkat Pendidikan}

Tingkat pendidikan adalah jenis pendidikan/sekolah formal tertinggi yang pernah diikuti oleh responden. Tingkat pendidikan dibagi menjadi dua kategori, yaitu rendah (tidak sekolah atau tamat $\mathrm{SD} /$ sederajat) dan tinggi (tamat SMP/sederajat atau tamat SMA/sederajat). Jumlah responden berpendidikan rendah sebanyak 23 orang $(76,7 \%)$ dan berpendidikan tinggi sebanyak 7 orang $(23,3 \%)$ dari keseluruhan responden. Hal tersebut menunjukkan bahwa sebagian besar responden berpendidikan rendah. Pendidikan adalah salah satu indikator yang dapat menggambarkan kualitas hidup sumberdaya manusia di suatu wilayah. Sebagian besar masyarakat yang sebelum terjadinya sedimentasi bekerja sebagai nelayan tidak menempuh atau hanya menamatkan jenjang pendidikan dasar.

Masyarakat yang termasuk kategori berpendidikan tinggi sebagian besar menamatkan pendidikannya melalui kejar paket A, B, dan C. Kejar paket tersebut merupakan bantuan pemerintah kepada beberapa masyarakat yang dianggap potensial untuk berkembang, baik secara sosial maupun karir pribadi. $^{3}$ Rendahnya pendidikan masyarakat di Desa Klaces dipengaruhi oleh ketersediaan sarana dan prasarana pendidikan saat responden mencapai usia sekolah. Sebagian responden juga beranggapan bahwa sekolah bukan sesuatu hal yang penting, sehingga tidak menjadi prioritas utama.

\section{Jumlah Anggota Keluarga}

Jumlah anggota keluarga adalah banyaknya orang yang memiliki hubungan kekerabatan dan menetap dalam satu rumah dimana responden itu tinggal. Jumlah anggota keluarga dibagi menjadi dua kategori, yaitu kecil (1-3 orang) dan besar (4-6 orang). Jumlah responden keluarga kecil sebanyak 15 orang $(50,0 \%)$ dan keluarga besar sebanyak 15 orang $(50,0 \%)$ dari keseluruhan responden. Hal tersebut menunjukkan bahwa jumlah dan persentase responden keluarga kecil dan besar adalah sama. Hal tersebut menandakan bahwa jumlah anggota keluarga di Desa Klaces sangat beragam.

\section{Lama Tinggal}

Lama tinggal adalah jangka waktu responden menetap di wilayah tempat penelitian hingga dilaksanakan penelitian. Lama tinggal dibagi menjadi dua kategori, yaitu baru (20-46 tahun) dan lama (47-77 tahun). Jumlah

\footnotetext{
${ }^{3}$ Sebagai contoh adalah perangkat desa
} 
responden dengan lama tinggal tergolong baru sebanyak 19 orang $(63,3 \%)$ dan lama sebanyak 11 orang $(36,7 \%)$ dari keseluruhan responden. Hal tersebut menunjukkan bahwa sebagian besar responden berada pada kategori baru. Diketahui berdasarkan fakta di lapangan bahwa masyarakat yang tergolong kategori lama (masyarakat asli) banyak yang telah meninggal dunia. Hal tersebut juga mengindikasikan bahwa masyarakat asli cenderung lebih sedikit dibandingkan pendatang.

\section{STRATEGI ADAPTASI DAN MOBILITAS SOSIAL NELAYAN PASCA SEDIMENTASI DAERAH ALIRAN SUNGAI (DAS)}

\section{Kondisi Pesisir Pasca Sedimentasi Daerah Aliran Sungai (DAS)}

Desa Klaces merupakan salah satu desa yang berada di sekitar perairan Segara Anakan. Perairan di sekitar Desa Klaces merupakan kawasan potensial tempat tumbuhnya mangrove, serta daerah pemijahan biota laut. Segara Anakan juga merupakan muara dari beberapa sungai, yaitu Sungai Citanduy, Cibeureum, Cikonde, Ujung Alang, dan sungai-sungai kecil lainnya. Tingginya laju sedimentasi dari sungai-sungai yang bermuara di Segara Anakan mengakibatkan berbagai bentuk perubahan ekologi. Perubahan ekologi di sekitar Segara Anakan antara lain: (1) perairan semakin dangkal, (2) timbulnya daratan baru, (3) luas perairan semakin sempit, (4) garis pantai semakin maju, (5) rusaknya mangrove, (6) perairan semakin kotor dan keruh, (7) rusaknya daerah pemijahan biota laut, dan (8) hilangnya berbagai spesies ikan dan hewan laut.

Semakin dangkalnya perairan di sekitar Desa Klaces merupakan akibat dari tertimbunnya lumpur sedimentasi dari berbagai sungai yang bermuara di Segara Anakan. Sedimentasi tersebut dari waktu ke waktu semakin meningkat hingga mengakibatkan timbulnya daratan baru yang saat ini dimanfaatkan oleh masyarakat Desa Klaces sebagai permukiman. Rumah yang dahulu sebelum terjadinya sedimentasi berupa rumah panggung yang berada di atas air, saat ini menjadi rumah-rumah permanen/non-permanen yang dibangun di atas tanah layaknya rumah di darat. Daratan-daratan baru inilah yang dikenal oleh masyarakat dengan istilah delta.

Timbulnya daratan-daratan baru secara otomatis memengaruhi luas perairan yang menjadi semakin sempit mengikuti laju kenaikan luas daratan. Akibat lainnya adalah semakin majunya garis pantai di wilayah sekitar Desa Klaces. Daratan baru tidak hanya timbul di daerah permukiman, tetapi juga di lahan tempat tumbuhnya mangrove. Sebelum terbentuknya daratan baru di lahan mangrove sebelah utara Desa Klaces, Desa Ujung Gagak dan Panikel terlihat jelas dari Desa Klaces. Seiring dengan proses sedimentasi, saat ini kedua desa tersebut tidak lagi terlihat dari Desa Klaces. Daratan baru di seberang darmaga Desa Klaces menjadi batas baru bagi desa-desa tersebut.
Mangrove membutuhkan sedimen untuk mempertahankan tempat pijakannya. Akan tetapi, kelimpahan jumlah sedimen juga dapat merusak pertumbuhan mangrove yang ada. Pendangkalan perairan mengakibatkan terbentuknya mangrove baru dan semakin dangkalnya perairan. Perubahan-perubahan yang terjadi tidak lepas dari proses konversi lahan mangrove oleh masyarakat setempat, sehingga semakin bertambahnya luas mangrove ternyata tidak sebanding dengan penurunan luasnya.

Sedimentasi juga berdampak pada kualitas air laut yang menjadi semakin kotor dan keruh. Perairan di sekitar Desa Klaces tidak lagi jernih, tetapi berwarna coklat lumpur. Semua bentuk perubahan-perubahan tersebut pada akhirnya memengaruhi ketersediaan sumberdaya pesisir terutama biota laut yang semakin menurun bahkan mulai hilang keragamannya. Kerusakan ekologi yang terjadi membawa dampak terhadap kehidupan masyarakat di Desa Klaces. Beberapa dampak sosialekonomi yang dialami oleh masyarakat Desa Klaces akibat perubahan ekologi pesisir antara lain: (1) berubahnya bentuk rumah, (2) kerugian ekonomi akibat banjir, (3) berubahnya pekerjaan utama, (4) menurunnya produktivitas perikanan, (5) berubahnya cara hidup masyarakat.

Perubahan utama pada kehidupan masyarakat di Desa Klaces pasca terjadinya sedimentasi adalah perubahan bentuk rumah. Seperti yang telah dijelaskan sebelumnya, timbulnya daratan baru mengakibatkan masyarakat harus melakukan penyesuaian bentuk rumah. Rumah yang awalnya berbentuk rumah panggung di atas air berubah menjadi rumah-rumah permanen/non-permanen di atas tanah. Saat ini, jarang ditemukan rumah masyarakat yang masih berbentuk rumah panggung. Perubahan bentuk rumah berdampak pada besarnya biaya yang harus dikeluarkan masyarakat untuk membeli bahan-bahan bangunan. Jauhnya jarak tempat membeli bahan-bahan bangunan serta tingginya biaya yang harus dikeluarkan untuk transportasi pengiriman bahan-bahan tersebut mengakibatkan semakin besarnya biaya yang dibutukan masyarakat untuk dapat beradaptasi terhadap perubahan yang terjadi.

Kondisi permukiman yang berada di tengah perairan mengakibatkan tingginya risiko terkena banjir saat air pasang. Terjadinya banjir akibat luapan air laut juga mengakibatkan tingginya biaya perbaikan bangunanbangunan fisik yang ada di Desa Klaces. Selain itu, banjir juga seringkali merupakan banjir kiriman dari hulu. Tidak hanya kerugian akibat rusaknya beberapa bangunan, banjir juga mengakibatkan rusaknya lahanlahan pertanian. Tingginya kadar garam air laut mengakibatkan tanaman di sawah rusak. Meskipun ada upaya penanggulangan berupa tanggul penahan air laut, tetapi saat pasang tinggi, sawah tetap terkena luapan air laut.

Selain perubahan bentuk rumah, perubahan pekerjaan mayarakat di Desa Klaces begitu mencolok pasca sedimentasi DAS. Sebelum terjadinya sedimentasi 
sebagian besar masyarakat bekerja sebagai nelayan, sedangkan setelah terjadinya sedimentasi sebagian besar masyarakat bekerja sebagai petani, baik petani pemilik maupun penggarap. Masyarakat yang tidak memiliki lahan atau tidak menggarap sawah biasanya ikut membantu pada saat panen (bawon). Luas perairan yang semakin sempit mengakibatkan semakin menyempitnya luas daerah tangkapan nelayan, bahkan semakin hilangnya berbagai jenis ikan. Hal tersebut berdampak pada penurunan produktivitas perikanan. Masyarakat yang masih tetap bertahan menjadi nelayan hingga saat ini hanyalah nelayan penangkap kepiting yang lebih dikenal dengan istilah nelayan madong.

Kegiatan mencari kepiting yang dilakukan masyarakat sangat terbatas pada waktu-waktu tertentu. Adanya tanah timbul memberikan alternatif lain bagi masyarakat sebagai sumber pekerjaan utama. Saat hasil tangkapan kepiting kurang mencukupi, maka masyarakat bercocok tanam di sawah. Perbedaan dari nelayan madong dan petani ini adalah waktu memperoleh pendapatan, dimana sebagai petani harus menunggu sampai panen tiba, sementara nelayan madong memperoleh hasil tepat setelah kepiting terkumpul. Penjualan kepiting dilakukan dengan beranekaragam cara, antara lain dijual langsung ke pembeli, tetangga, dan/atau dijual ke bos kepiting.

Selain menjadi petani, masyarakat juga melakukan konversi lahan untuk lahan tambak. Pendatanglah yang mengenalkan masyarakat setempat dengan cara-cara bertambak. Akan tetapi, tambak-tambak milik mayarakat tidak terawat lagi akibat kurangnya keahlian dan modal masyarakat setempat untuk terus mengelola tambak. Saat membuka lahan tambak, masyarakat hanya bermodalkan kemauan dan kesempatan tanpa adanya pengetahuan yang cukup mengenai bertambak. Masyarakat cenderung ingin mencoba segala upaya yang bisa membantu meningkatkan pendapatannya tanpa memikirkan kerugian-kerugian yang akan terjadi.

Cara hidup tersebut biasa dilakukan masyarakat Desa Klaces, dimana masyarakat akan mengerjakan pekerjaan apapun yang memungkinkan untuk dikerjakan. Masyarakat berupaya untuk memanfaatkan semua peluang yang ada untuk dapat meningkatkan pendapatan keluarga. Hal tersebut menjadi sebuah kelebihan bagi masyarakat di Desa Klaces, dimana masyarakat memiliki daya juang yang tinggi untuk bisa beradaptasi dengan perubahan yang terjadi.

Berbagai upaya penanggulangan dampak negatif sedimentasi telah dilakukan oleh pemerintah. Salah satunya adalah pengerukan Segara Anakan yang berdampak pada bertambahnya luas perairan menjadi 700 hektar dari luas awal 600 hektar. ${ }^{4}$ Hasil perikanan pasca pengerukan menjadi meningkat, tanah hasil pengerukan yang ditimbun di permukiman pun dimanfaatkan sebagai lahan pertanian yang hasil panennya cukup baik. Namun, besarnya biaya pengerukan tidak sebanding dengan cepatnya proses sedimentasi terjadi. Tidak lama setelah

\footnotetext{
4 Tahun 2002-2005.
}

pengerukan dilakukan, sedimentasi kembali mengakibatkan perairan dangkal. Masyarakat di Desa Klaces memahami mengenai kondisi Desa Klaces yang berada di hilir sungai. Masyarakat memandang dampakdampak sedimentasi tersebut sebagai konsekuensi dari letak desa yang merupakan muara dari sungai-sungai di hulu. Upaya lain yang masih direncanakan oleh pemerintah untuk menanggulangi dampak-dampak negatif sedimentasi adalah rencana penyodetan yang diarahkan ke Pangandaran melalui Ciamis. Namun, hingga saat ini rencana tersebut masih terkendala masalah birokrasi dan kewenangan dari dua provinsi yang berbeda, yaitu Jawa Tengah dan Jawa Barat. Masyarakat pun tidak banyak berharap rencana itu akan berhasil karena masyarakat meyakini bahwa masyarakat di sekitar Pangandaran tidak akan mau menerima kiriman sedimen dari sungai-sungai di hulu.

Selain menanggulangi dampak ekologi dari sedimentasi DAS, pemerintah juga turut serta dalam upaya peningkatan taraf hidup masyarakat di Desa Klaces yang telah mengalami perubahan sosial-ekonomi pasca sedimentasi DAS. Intervensi pemerintah di Desa Klaces terlihat dari beberapa program pemerintah yang diterapkan di desa ini. Salah satu bentuk intervensi tersebut adalah adanya PNPM $^{5}$ Mandiri Perdesaan dalam berbagai aspek kehidupan. Program ini telah membantu masyarakat dalam memperbaiki kondisi sosialekonominya. Beberapa program yang dirasakan bermanfaat bagi masyarakat adalah pembangunan dan perbaikan jalan, penyediaan sarana dan prasarana pendidikan, pemberian pupuk dan benih/bibit padi, serta program pinjaman dana kepada masyarakat Desa Klaces. Program pembangunan desa yang merupakan bagian dari PNPM Mandiri Perdesaan banyak dimanfaatkan masyarakat sebagai sumber pendapatan, karena apabila ada program pembangunan, masyarakat turut serta menjadi buruh bangunan. Setelah terjadinya sedimentasi DAS, beberapa masyarakat juga telah menikmati bantuan pemerintah berupa bantuan melanjutkan pendidikan melalui kejar paket $\mathrm{A}, \mathrm{B}$, dan $\mathrm{C}$, serta beasiswa kuliah bagi siswa berprestasi. Bantuan inilah yang kemudian meningkatkan kualitas sumberdaya manusia yang ada di Desa Klaces.

\section{Strategi Adaptasi Nelayan}

Strategi adaptasi nelayan adalah pilihan tindakan yang dilakukan nelayan dalam menyiasati dampak negatif dari perubahan ekologi yang memengaruhi aktivitasnya. Strategi adaptasi nelayan tersebut meliputi jejaring/hubungan sosial, pola nafkah ganda, mobilisasi peran keluarga, migrasi, alih mata pencaharian, dan strategi adaptasi lainnya. Variabel-variabel strategi adaptasi nelayan terdiri dari dua kategori, yaitu kategori rendah dan kategori tinggi. ${ }^{6}$

\footnotetext{
5 Program Nasional Pemberdayaan Masyarakat.

${ }^{6}$ Kategori rendah mewakili tidak adanya pilihan strategi adaptasi dan kategori tinggi mewakili adanya pilihan strategi adaptasi.
} 


\section{Jejaring/Hubungan Sosial}

Jejaring/hubungan sosial adalah hubungan yang dijalin nelayan dalam menghadapi perubahan ekologi meliputi hubungan dengan saudara, tetangga, bos kepiting, dan/atau pemerintah desa saat mengalami permasalahan ekonomi. Jejaring/hubungan sosial dibagi menjadi dua kategori, yaitu rendah (skor 1-4) dan tinggi (skor 5-8). Jumlah responden pada kategori rendah sebanyak 2 orang $(6,7 \%)$ dan pada kategori tinggi sebanyak 28 orang $(93,3 \%)$ dari keseluruhan responden. Data tersebut menunjukkan bahwa sebagian besar responden melakukan strategi adaptasi jejaring/hubungan sosial. Ada beberapa faktor penyebab kondisi tersebut, yaitu:

1. Hubungan kekerabatan antara masyarakat Desa Klaces cukup erat, sehingga tidak sulit bagi masyarakat untuk meminta bantuan di saat mengalami kesulitan ekonomi.

2. Masyarakat menganggap bahwa meminta bantuan berupa pinjaman kepada saudara dan tetangga tidak sulit karena hanya bermodalkan kepercayaan satu sama lain. Begitu juga dengan meminta bantuan kepada bos kepiting yang dianggap tidak memberatkan karena masyarakat bisa membayar pinjaman dengan hasil tangkapan kepiting yang waktunya tidak ditentukan.

Saat mengalami kesulitan ekonomi, sebagian besar masyarakat di Desa Klaces merasa lebih nyaman meminta bantuan kepada saudara, tetangga, dan bos kepiting dibandingkan kepada pemerintah desa. Hanya beberapa masyarakat yang pernah meminta bantuan pemerintah desa terkait masalah ekonomi. Hal tersebut dikarenakan adanya perasaan segan untuk meminta bantuan kepada pemerintah desa. Masalah yang dialami masyarakat adalah jika pada saat yang bersamaan, responden, saudara, tetangga, atau bos kepiting mengalami kesulitan ekonomi juga, sehingga tidak adanya tempat untuk meminta bantuan.

Selain meminjam kepada saudara, tetangga, bos kepiting, dan/atau pemerintah desa, masyarakat di Desa Klaces juga mengikuti program pemerintah yang memberikan bantuan berupa pinjaman kepada masyarakat setempat. Adanya bantuan berupa pinjaman dari PNPM Mandiri Perdesaan merupakan alternatif baru yang dianggap sangat membantu masyarakat. Beberapa masyarakat meminjam pada PNPM Mandiri Perdesaan dengan alasan mengikuti tetangga-tetangga lain yang juga meminjam. Hampir seluruh masyarakat di Desa Klaces ikut serta dalam program tersebut.

\section{Pola Nafkah Ganda}

Pola nafkah ganda adalah penganekaragamaan jenis pekerjaan, baik sektor pertanian maupun non-pertanian. Pola nafkah ganda dibagi menjadi dua kategori, yaitu rendah (skor 1-5) dan tinggi (skor 6-10). Jumlah responden pada kategori rendah sebanyak 1 orang $(3,3 \%)$ dan pada kategori tinggi sebanyak 29 orang $(96,7 \%)$ dari keseluruhan responden. Berdasarkan data tersebut diketahui bahwa sebagian besar responden melakukan strategi adaptasi pola nafkah ganda. Ada beberapa faktor penyebab kondisi tersebut, yaitu:

1. Tidak mencukupinya pendapatan dari satu jenis pekerjaan.

2. Beragamnya jenis pekerjaan di Desa Klaces yang bisa dijadikan sebagai pekerjaan sampingan oleh masyarakat.

3. Masyarakat cenderung berusaha melakukan berbagai jenis pekerjaan untuk meningkatkan pendapatan keluarga.

Beragam pekerjaan yang dilakukan masyarakat disesuaikan dengan kondisi yang ada. Pekerjaan yang paling sering dilakukan oleh masyarakat adalah bertani dan madong. Jika hasil tangkapan kepiting meningkat, maka masyarakat bekerja sebagai nelayan madong. Jika kondisi pertanian sedang baik, maka masyarakat bekerja sebagai petani. Disamping itu, beberapa masyarakat memilih menjadi buruh bangunan jika ada proyek PNPM Mandiri Perdesaan di desa. ${ }^{7}$ Bagi masyarakat, pekerjaan apapun yang ada di desa akan mereka lakukan jika ada kesempatan dan kemampuan.

\section{Mobilisasi Peran Keluarga}

Mobilisasi peran keluarga adalah pembagian kerja di antara anggota keluarga dengan menyertakan istri dan/atau anak untuk bekerja. Mobilisasi peran keluarga dibagi menjadi dua kategori, yaitu rendah (skor 1-2) dan tinggi (skor 3-4). Jumlah responden pada kategori rendah sebanyak 6 orang $(20,0 \%)$ dan pada kategori tinggi sebanyak 24 orang $(80,0 \%)$ dari keseluruhan responden. Berdasarkan data tersebut diketahui bahwa sebagian besar responden melakukan strategi adaptasi mobilisasi peran keluarga. Ada beberapa faktor penyebab kondisi tersebut, yaitu:

1. Masyarakat di Desa Klaces beraganggapan bahwa apapun pekerjaan yang ada selama masih mampu maka akan dilakukan, termasuk mengikutsertakan anggota keluarga dalam mencari nafkah.

2. Beberapa istri di Desa Klaces memilih untuk bekerja demi meningkatkan pendapatan keluarga. Sebagian ada yang bekerja sebagai pedagang dengan membuka warung kecil di rumahnya dan sebagian ada yang membantu suami bekerja di sawah.

3. Keikutsertaan anak dalam bekerja sebagian besar karena tidak lagi menempuh jenjang pendidikan. Beberapa anak dalam keluarga memilih untuk bekerja daripada hanya menganggur di rumah.

\section{Migrasi}

Migrasi adalah kegiatan nelayan untuk keluar dari desa dalam upaya mencari pekerjaan di daerah lain. Migrasi dibagi menjadi dua kategori, yaitu rendah (skor 1-2) dan tinggi (skor 3-4). Jumlah responden pada kategori rendah sebanyak 25 orang $(83,3 \%)$ dan pada kategori tinggi

\footnotetext{
7 Salah satu program PNPM Mandiri Perdesaan yang saat ini sedang berjalan adalah pembangunan PAUD di Dusun Klaces.
} 
sebanyak 5 orang $(16,7 \%)$ dari keseluruhan responden. Berdasarkan data tersebut diketahui bahwa sebagian besar responden tidak melakukan strategi adaptasi migrasi. Ada beberapa faktor penyebab kondisi tersebut, yaitu:

1. Pandangan masyarakat bahwa bekerja di daerah sendiri jauh lebih baik daripada di daerah lain.

2. Tidak adanya keterampilan memaksa masyarakat untuk tetap bertahan dengan kondisi apapun yang terjadi di Desa Klaces. Adapun masyarakat yang melakukan migrasi adalah masyarakat dengan kondisi fisik yang relatif masih kuat.

\section{Alih Mata Pencaharian}

Alih mata pencaharian adalah mengubah pekerjaan utama dengan tidak lagi bekerja sebagai nelayan atau menjadikan nelayan sebagai pekerjaan sampingan. Alih mata pencaharian dibagi menjadi dua kategori, yaitu rendah (skor 1-2) dan tinggi (skor 3). Jumlah responden pada kategori rendah sebanyak 12 orang $(40,0 \%)$ dan pada kategori tinggi sebanyak 18 orang $(60,0 \%)$ dari keseluruhan responden. Berdasarkan data tersebut diketahui bahwa sebagian besar responden melakukan strategi adaptasi alih mata pencaharian. Ada beberapa faktor penyebab kondisi tersebut, yaitu:

1. Pendapatan yang tidak mencukupi dari pekerjaan terdahulu (nelayan). Turunnya produktivitas perikanan mengakibatkan semakin rendahnya pendapatan nelayan sehingga masyarakat memilih pekerjaan lain sebagai pekerjaan utamanya.

2. Kondisi diri yang tidak cocok lagi dengan pekerjaan terdahulu (nelayan). Masyarakat yang tidak lagi bekerja sebagai nelayan karena kondisi fisik yang sudah tidak sanggup lagi untuk melaut.

\section{Strategi Adaptasi Lainnya}

Strategi adaptasi lainnya adalah kegiatan yang dilakukan nelayan selain dari yang disebutkan sebelumnya untuk meningkatkan pendapatan keluarga, meliputi menjual/menggadaikan aset/barang dimiliki, serta pemanfaatan hasil hutan. Strategi adaptasi lainnya dibagi menjadi dua kategori, yaitu rendah (skor 1-2) dan tinggi (skor 3-4). Jumlah responden pada kategori rendah sebanyak 12 orang $(40,0 \%)$ dan pada kategori tinggi sebanyak 18 orang $(60,0 \%)$ dari keseluruhan responden. Berdasarkan data tersebut diketahui bahwa sebagian besar responden melakukan strategi adaptasi lainnya. Ada beberapa faktor penyebab kondisi tersebut, yaitu:

1. Tidak mungkin lagi melakukan strategi adaptasi jejaring/hubungan sosial, pola nafkah ganda, mobilisasi peran keluarga, migrasi, dan alih mata pencaharian. Hal tersebut dikarenakan berbagai alasan, mulai dari kondisi kerabat yang mengalami kesulitan yang sama pada waktu yang sama, kondisi pekerjaan yang tidak baik, kondisi diri dan keluarga yang tidak mendukung, sampai kondisi keuangan yang terlalu mendesak.
2. Masyarakat masih memiliki aset/barang yang bisa dijual/digadaikan serta tersedianya beberapa sumberdaya hutan yang bisa dimanfaatkan secara bebas.

Masyarakat biasanya melakukan strategi ini jika dalam kondisi mendesak. Utamanya masyarakat memilih untuk menjual/menggadaikan aset/barang yang dimiliki, baik berupa barang elektronik, kendaraan, emas, dsb. Selain itu, tidak jarang masyarakat mengupayakan hasil hutan berupa kayu bakar, kayu bangunan, dan beberapa hasil hutan yang masih bisa dimanfaatkan untuk memenuhi kebutuhan sehari-hari. ${ }^{8}$ Strategi adaptasi lainnya ini merupakan upaya terakhir yang bisa dilakukan masyarakat pada saat mengalami kesulitan ekonomi.

\section{Mobilitas Sosial Nelayan}

\section{Stratifikasi Sosial}

Pekerjaan di Desa Klaces saat ini beranekaragam sesuai dengan perkembangan yang terjadi dari tahun ke tahun. Pekerjaan yang ada menjadi dasar stratifikasi sosial masyarakat di Desa Klaces. Stratifikasi sosial masyarakat yang ada di Desa Klaces berdasarkan hasil survai dengan menggunakan pendekatan reputasional dapat dilihat pada Tabel 1.

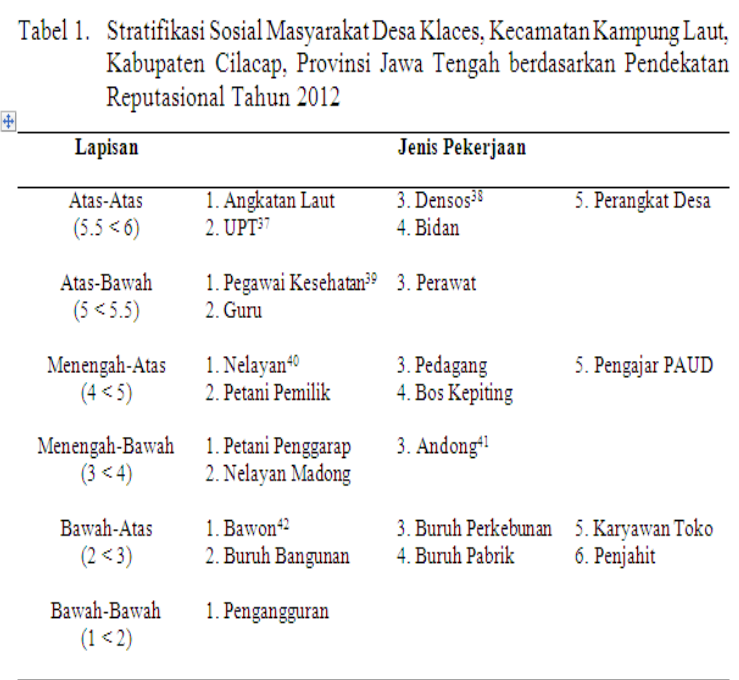

Sumber: Data primer diolah, 2012

Sistem stratifikasi sosial masyarakat Desa Klaces tergolong sistem stratifikasi sosial terbuka, dimana sistem status yang berlaku merupakan hasil usaha-usaha seseorang yang disengaja (achieved status). Kedudukan dalam masyarakat diperoleh berdasarkan usaha sendiri yang dilihat dari jenis pekerjaan. Stratifikasi sosial berdasarkan pekerjaan tersebut menjadi acuan dalam menentukan mobilitas sosial nelayan. Mobilitas sosial nelayan adalah perubahan posisi atau status sosial nelayan dalam struktur sosial masyarakat berdasarkan pekerjaan. Mobilitas sosial nelayan meliputi tipe

\footnotetext{
${ }^{8}$ Kayu yang diambil masyarakat adalah kayu-kayu kering di lahan mangrove dan Nusakambangan. Kayu-kayu tersebut adalah kayu yang memang dapat diambil secara bebas.
} 
mobilitas sosial intra-generasi dan tipe mobilitas sosial antar-generasi.

\section{Mobilitas Sosial Intra-Generasi}

Tipe mobilitas sosial intra-generasi adalah peralihan kedudukan atau peran sosial masyarakat dalam status pekerjaan, baik secara horizontal, maupun vertikal (naik ataupun turun) yang terjadi pada nelayan (responden) itu sendiri. Tipe mobilitas sosial intra-generasi dibagi menjadi tiga kategori, yaitu turun (mobilitas vertikal turun), tetap (mobilitas horizontal), dan naik (mobilitas vertikal naik). Jumlah responden yang mengalami mobilitas sosial intra-generasi turun sebanyak 15 orang $(50,0 \%)$, tetap sebanyak 10 orang $(33,3 \%)$, dan naik sebanyak 5 orang $(16,7 \%)$ dari keseluruhan responden. Berdasarkan data tersebut diketahui bahwa seluruh responden mengalami mobilitas sosial, baik mobilitas sosial turun, tetap, maupun naik. Sebagian besar responden mengalami mobilitas sosial turun. Ada beberapa faktor penyebab kondisi tersebut, yaitu:

1. Pekerjaan yang dipilih masyarakat sebagai pekerjaan utama (pengganti pekerjaan terdahulu) sebagian besar berada pada posisi yang lebih rendah daripada pekerjaan terdahulu berdasarkan stratifikasi sosial masyarakat.

2. Rendahnya tingkat pendidikan dan kurangnya keterampilan masyarakat untuk bisa mendapatkan pekerjaan yang posisinya berada pada lapisan atas.

Mobilitas sosial tersebut digambarkan dengan menggunakan piramida mobilitas sosial yang dapat dilihat pada Gambar 3.

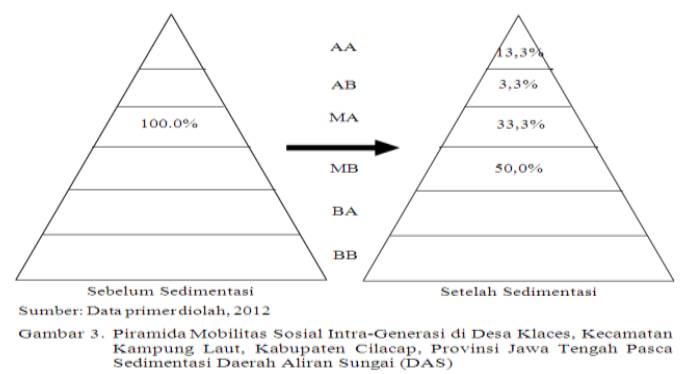

Berdasarkan hasil survai menggunakan pendekatan reputasional, diketahui bahwa nelayan di Desa Klaces dikategorikan berada pada lapisan menengah-atas pada stratifikasi sosial. Kondisi ini dikarenakan sebelum sedimentasi terjadi, sebagian besar masyarakat di Desa Klaces bekerja sebagai nelayan sehingga tidak beragamnya pekerjaan yang dapat dibandingkan untuk menentukan posisi pada stratifikasi sosial. Selain itu, masyarakat juga beranggapan bahwa saat masih menjadi nelayan (sebelum sedimentasi), pendapatan dari satu jenis pekerjaan (nelayan) sudah mampu mencukupi kebutuhan hidup sehari-hari. Meskipun perahu dan alatalat melaut yang digunakan masih tergolong tradisional, tetapi hasil melaut mampu mensejahterahkan kehidupan nelayan di Desa Klaces. Adanya golongan pengangguran juga memengaruhi posisi pekerjaan pada stratifikasi sosial, karena pada lapisan terbawah di Desa Klaces bukanlah diisi oleh jenis pekerjaan tertentu yang ada di Desa Klaces, melainkan oleh status pengangguran yang dalam hal ini dikategorikan pula sebagai status pekerjaan (mewakili jenis pekerjaan untuk masyarakat yang tidak bekerja).

\section{Mobilitas Sosial Antar-generasi}

Tipe mobilitas sosial antar-generasi adalah peralihan kedudukan atau peran sosial masyarakat dalam status pekerjaan, baik secara horizontal, maupun vertikal (naik ataupun turun) yang terjadi pada keluarga nelayan (responden) pada generasi berikutnya (anak responden). Tipe mobilitas sosial antar-generasi dibagi menjadi tiga kategori, yaitu turun (mobilitas vertikal turun), tetap (mobilitas horizontal), dan naik (mobilitas vertikal naik). Jumlah responden yang mengalami mobilitas sosial antar-generasi turun sebanyak 16 orang $(61,5 \%)$, tetap sebanyak 2 orang $(7,7 \%)$, dan naik sebanyak 8 orang $(30,8 \%)$ dari keseluruhan responden.

Berdasarkan hasil survai diketahui bahwa dari 30 responden penelitian, 13 responden yang memiliki anak telah bekerja. Dari 13 responden tersebut, diperoleh data 26 anak responden dengan beragam pekerjaan. Data tersebut menjadi landasan untuk menentukan mobilitas sosial antar-generasi. Seluruh anak responden mengalami mobilitas sosial, baik mobilitas sosial turun, tetap, maupun naik. Sebagian besar mengalami mobilitas sosial turun. Ada beberapa faktor penyebab kondisi tersebut, yaitu:

1. Anak dalam keluarga di Desa Klaces yang mengalami mobilitas turun sebagian besar karena faktor rendahnya pendidikan, sedangkan anak dalam keluarga di Desa Klaces yang berpendidikan tinggi cenderung banyak yang bekerja sebagai pegawai pemerintah, baik di tingkat desa, maupun kota.

2. Mobilitas sosial yang dialami anak dalam keluarga sangat erat kaitannya dengan status ayah (responden) saat ini (rendah atau tinggi). Ketika status ayah rendah, maka posisi anak pada stratifikasi sosial pun rendah sehingga memengaruhi mobilitas sosialnya. Begitu juga dengan status ayah yang tinggi.

Mobilitas sosial tersebut digambarkan dengan menggunakan piramida mobilitas sosial yang dapat dilihat pada Gambar 4.

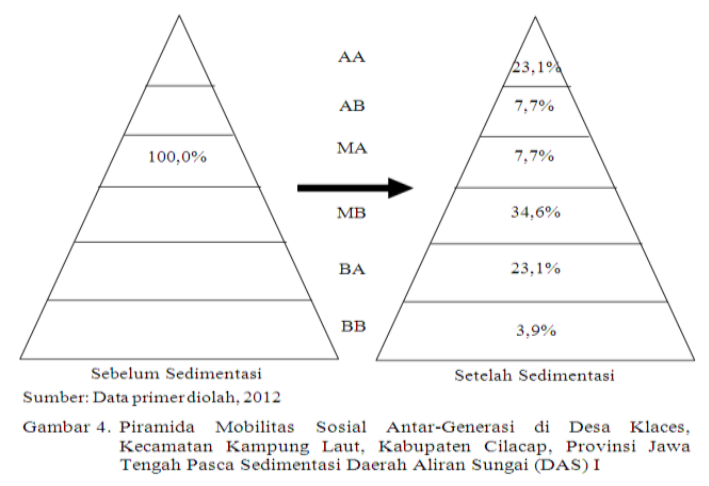

Sodality: Jurnal Sosiologi Pe 
Pada Gambar 5 berikut dapat dilihat gambaran mobilitas sosial antar-generasi dengan mengambil data anak responden yang memiliki pekerjaan tertinggi pada lapisan stratifikasi sosial. Jumlah data yang diambil adalah sejumlah responden yang memiliki anak telah bekerja, yaitu 13 responden dengan 13 data anak.

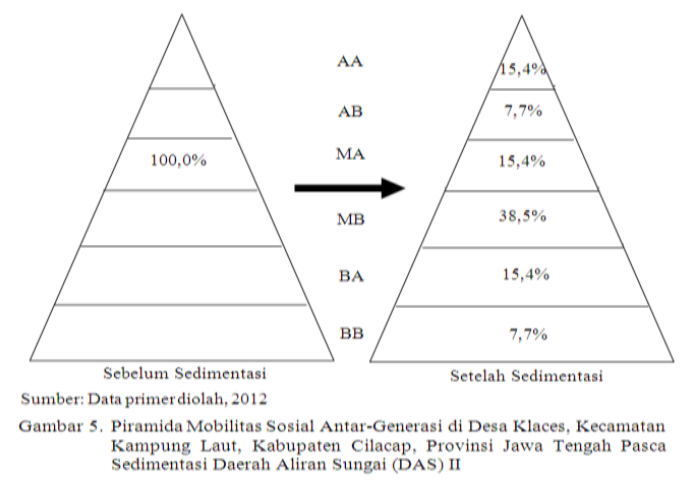

Apabila Gambar 4 dan 5 dibandingkan, maka terlihat bahwa persentase terbesar berada pada lapisan yang sama, yaitu lapisan menengah-bawah. Hal tersebut menandakan bahwa sebagian besar anak dalam keluarga di Desa Klaces memiliki pekerjaan lebih rendah dibandingkan pekerjaan ayah (responden) sebelum terjadi sedimentasi berdasarkan stratifikasi sosialnya.

\section{ANALISIS HUBUNGAN KARAKTERISTIK RESPONDEN, STRATEGI ADAPTASI NELAYAN, DAN MOBILITAS SOSIAL NELAYAN}

\section{Analisis Hubungan Karakteristik Responden dengan Strategi Adaptasi Nelayan}

\section{Hubungan Karakteristik Responden dengan Strategi Adaptasi Jejaring/Hubungan Sosial}

Hasil analisis data menunjukkan bahwa karakteristik usia, tingkat pendidikan, dan lama tinggal yang berbeda tidak berhubungan dengan pilihan strategi adaptasi jejaring/hubungan sosial. Perbedaan kategori usia, tingkat pendidikan, dan lama tinggal tidak memengaruhi rendah atau tingginya strategi adaptasi jejaring/hubungan sosial. Namun, karakteristik jumlah anggota keluarga berhubungan dengan pilihan strategi adaptasi jejaring/hubungan sosial. Semakin besar jumlah anggota keluarga maka responden cenderung melakukan strategi adaptasi jejaring/hubungan sosial. Gambar 6 menyajikan data mengenai persentase hubungan antara karakteristik responden dengan strategi adaptasi jejaring/hubungan sosial.

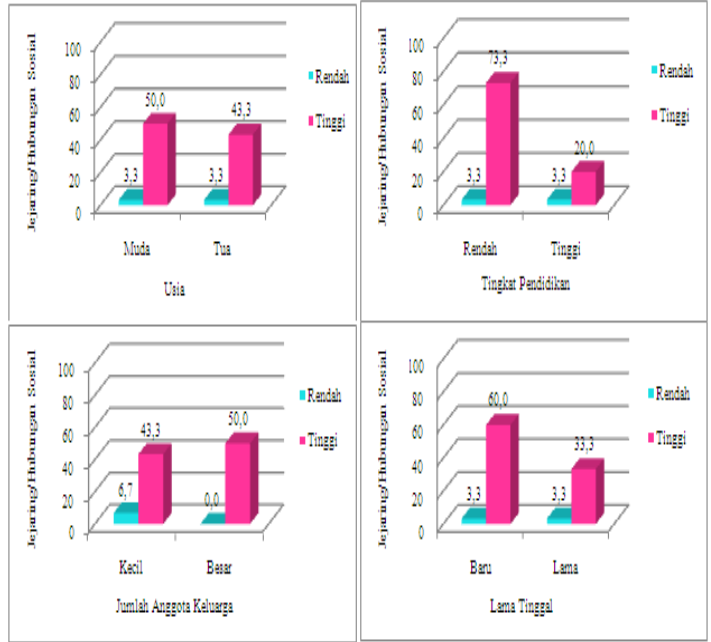

Sumber: Data primer diolah, 2012

Gambar 6. Persentase Hubungan antaraKarakteristik Responden dengan Strategi Adaptasi Jejaring Hubungan Sosial di Desa Klaces, Kecamatan Kampung Laut, Kabupaten Cilacap, Provinsi Jawa Tengah Tahun 2012

Hasil penelitian menunjukkan bahwa:

1. Jumlah anggota keluarga memengaruhi pilihan strategi adaptasi jejaring/hubungan sosial karena semakin besar suatu keluarga maka semakin besar biaya hidup untuk mencukupi kebutuhan seharihari. Fakta di lapangan menunjukkan bahwa banyak keluarga di Desa Klaces yang tergolong keluarga besar dengan pendapatan kepala keluarga relatif rendah sehingga seringkali harus meminta bantuan kepada saudara, tetangga, bos kepiting, ataupun pemerintah desa untuk memenuhi kebutuhan seharihari.

2. Hal yang umumnya memengaruhi pilihan strategi adaptasi jejaring/hubungan sosial adalah kondisi ekonomi keluarga. Masyarakat ekonomi tinggi cenderung tidak melakukan strategi adaptasi jejaring/hubungan sosial, tetapi sebaliknya masyarakat ekonomi menengah atau rendah cenderung melakukan strategi adaptasi jejaring/hubungan sosial. Masyarakat ekonomi tinggi beranggapan bahwa dirinya sudah mampu untuk mencukupi kebutuhan sehari-hari tanpa harus meminta bantuan kepada saudara, tetangga, bos kepiting, ataupun pemerintah desa.

Hubungan Karakteristik Responden dengan Strategi Adaptasi Pola Nafkah Ganda

Hasil analisis data menunjukkan bahwa karakteristik usia yang berbeda tidak berhubungan dengan pilihan strategi adaptasi pola nafkah ganda. Perbedaan kategori usia tidak memengaruhi rendah atau tingginya strategi adaptasi pola nafkah ganda. Namun, karakteristik tingkat pendidikan, jumlah anggota keluarga, dan lama tinggal berhubungan dengan pilihan strategi adaptasi pola nafkah ganda. Semakin tinggi pendidikan maka responden 
cenderung tidak melakukan strategi pola nafkah ganda, semakin besar jumlah anggota keluarga maka responden cenderung melakukan strategi adaptasi pola nafkah ganda, serta semakin lama tinggal maka responden cenderung tidak melakukan strategi adaptasi pola nafkah ganda. Gambar 7 menyajikan data mengenai persentase hubungan antara karakteristik responden dengan strategi adaptasi pola nafkah ganda.

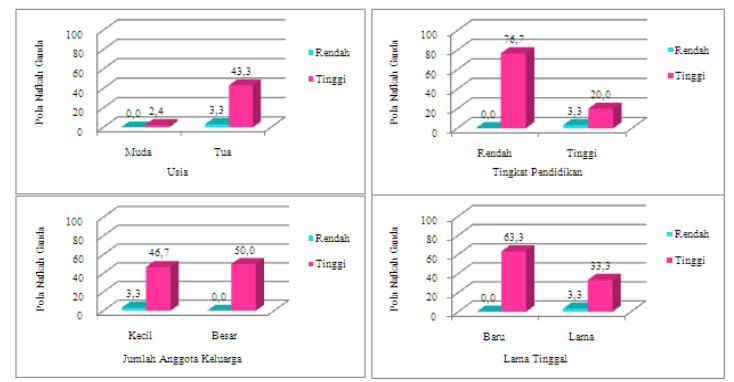

Sumber: Data primer diolah, 2012

Gambar 7. Persentase Hubungan antara Karakteristik Responden dengan Strategi Adaptasi Pola Nafkah Ganda di Desa Klaces, Kecamatan Kampung Laut, Kabupaten Cilacap, Provinsi Jawa Tengah Tahun 2012

Hasil penelitian menunjukkan bahwa:

1. Tingkat pendidikan memengaruhi pilihan strategi adaptasi pola nafkah ganda karena masyarakat yang berpendidikan tinggi biasanya telah memiliki pekerjaan yang cukup memadai dilihat dari sisi pendapatan sehingga tidak lagi mencari pekerjaan sampingan. Sementara masyarakat yang berpendidikan rendah biasanya berusaha mencoba semua peluang kerja untuk meningkatkan pendapatan keluarga, termasuk menganekaragamkan pekerjaan.

2. Masyarakat yang memiliki keluarga besar, biasanya melakukan strategi adaptasi pola nafkah ganda karena pengaruh jumlah anggota keluarga yang membutuhkan biaya hidup besar, sedangkan pendapatan dari satu jenis pekerjaan belum bisa mencukupi kebutuhan tersebut.

3. Masyarakat yang telah lama tinggal di Desa Klaces, biasanya telah memiliki pekerjaan tetap yang cukup memadai dilihat dari sisi pendapatan sehingga cenderung tidak melakukan strategi adaptasi ini.

4. Hal yang umumnya memengaruhi pilihan strategi adaptasi pola nafkah ganda adalah kesempatan dan kemampuan. Bagi masyarakat jika memiliki kemampuan untuk melakukan beragam pekerjaan dan ditunjang dengan adanya kesempatan, maka masyarakat cenderung akan melakukan pekerjaan apapun yang dapat meningkatkan pendapatan keluarga.

\section{Hubungan Karakteristik Responden dengan Strategi Adaptasi Mobilisasi Peran Keluarga}

Hasil analisis data menunjukkan bahwa karakteristik usia, tingkat pendidikan, dan lama tinggal yang berbeda tidak berhubungan dengan pilihan strategi adaptasi mobilisasi peran keluarga. Perbedaan kategori usia, tingkat pendidikan, dan lama tinggal tidak memengaruhi rendah atau tingginya strategi adaptasi mobilisasi peran keluarga. Namun, karakteristik jumlah anggota keluarga berhubungan dengan pilihan strategi adaptasi mobilisasi peran keluarga. Semakin besar jumlah anggota keluarga maka responden cenderung melakukan strategi adaptasi mobilisasi peran keluarga. Gambar 8 menyajikan data mengenai persentase hubungan antara karakteristik responden dengan strategi adaptasi mobilisasi peran keluarga.

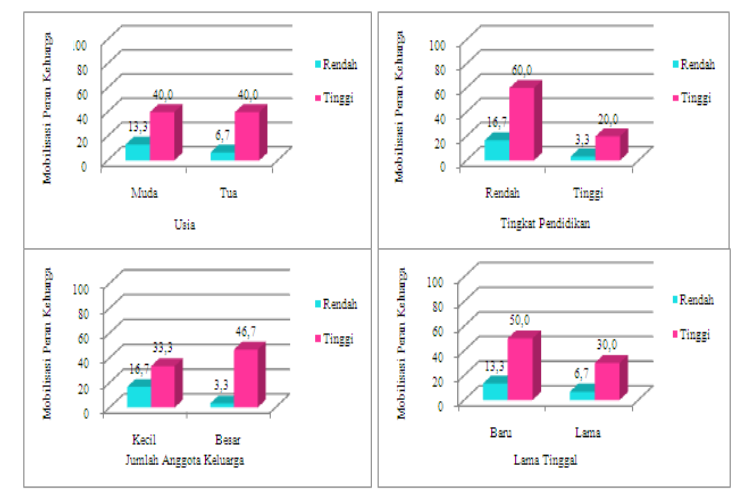

Sumber: Data primer diolah, 2012

Gambar 8. Persentase Hubungan antara Karakteristik Responden dengan Strategi Adaptasi Mobilisasi Peran Keluarga di Desa Klaces, Kecamatan Kampung Laut, Kabupaten Cilacap, Provinsi Jawa TengahTahun 2012

Hasil penelitian menunjukkan bahwa:

1. Jumlah anggota keluarga memengaruhi pilihan strategi adaptasi mobilisasi peran keluarga karena merupakan suatu kelaziman di Desa Klaces ketika seluruh anggota keluarga bekerja membantu meningkatkan pendapatan keluarga.

2. Hal yang umumnya memengaruhi pilihan strategi adaptasi mobilisasi peran keluarga adalah kondisi anggota keluarga. Jika istri memiliki kemampuan secara fisik untuk bekerja, maka istri akan terlibat dalam pencarian nafkah keluarga. Sementara anak yang terlibat mencari nafkah dikarenakan usianya telah memasuki usia kerja atau tidak lagi menempuh jenjang pendidikan.

\section{Hubungan Karakteristik Responden dengan Strategi Adaptasi Migrasi}

Hasil analisis data menunjukkan bahwa karakteristik usia, tingkat pendidikan, dan lama tinggal yang berbeda tidak berhubungan dengan pilihan strategi adaptasi migrasi. Perbedaan kategori usia, tingkat pendidikan, dan lama tinggal tidak memengaruhi rendah atau tingginya strategi adaptasi migrasi. Namun, karakteristik jumlah anggota keluarga berhubungan dengan pilihan strategi adaptasi migrasi. Semakin besar jumlah anggota keluarga maka responden cenderung melakukan strategi adaptasi migrasi. Gambar 9 menyajikan data mengenai persentase hubungan antara karakteristik responden dengan strategi adaptasi migrasi. 


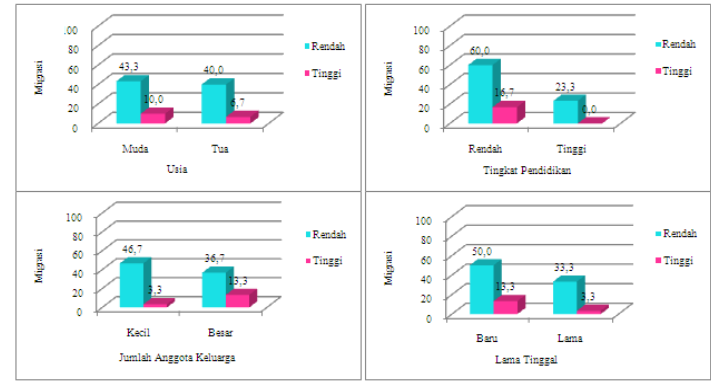

Sumber: Data primer diolah, 2012

Gambar 9. Persentase Hubungan antara Karakteristik Responden dengan Strategi Adaptasi Migrasi di Desa Klaces, Kecamatan Kampun Laut, Kabupaten Cilacap, Provinsi Jawa Tengah Tahun 2012

Hasil penelitian menunjukkan bahwa:

1. Jumlah anggota keluarga memengaruhi pilihan strategi adaptasi migrasi karena sebagian besar masyarakat di Desa Klaces yang melakukan migrasi adalah masyarakat dengan keluarga kategori besar. Meskipun fakta di lapangan menunjukkan bahwa hanya sebagian kecil masyarakat yang melakukan migrasi, tetapi ketika ada peluang bekerja di luar desa, masyarakat pun tidak segan untuk mencobanya.

2. Hal yang umumnya memengaruhi pilihan strategi adaptasi migrasi adalah ada atau tidaknya kemampuan/keterampilan yang bisa menjadi bekal bekerja di luar desa. Faktor fisik dan anggapan bahwa bekerja di desa jauh lebih baik juga memengaruhi pilihan adaptasi ini. Adapun masyarakat yang melakukan migrasi masih terbatas pada masyarakat dengan kondisi fisik yang masih relatif kuat.

\section{Hubungan Karakteristik Responden dengan Strategi Adaptasi Alih Mata Pencaharian}

Hasil analisis data menunjukkan bahwa karakteristik tingkat pendidikan yang berbeda tidak berhubungan dengan pilihan strategi adaptasi alih mata pencaharian. Perbedaan kategori tingkat pendidikan tidak memengaruhi rendah atau tingginya strategi adaptasi alih mata pencaharian. Namun, karakteristik usia, jumlah anggota keluarga, dan lama tinggal berhubungan dengan pilihan strategi adaptasi alih mata pencaharian. Semakin tua usia maka responden cenderung melakukan strategi adaptasi alih mata pencaharian, semakin besar jumlah anggota keluarga maka responden cenderung melakukan strategi adaptasi alih mata pencaharian, serta semakin lama tinggal maka responden cenderung melakukan strategi adaptasi alih mata pencaharian. Gambar 10 menyajikan data mengenai persentase hubungan antara karakteristik responden dengan strategi adaptasi alih mata pencaharian.

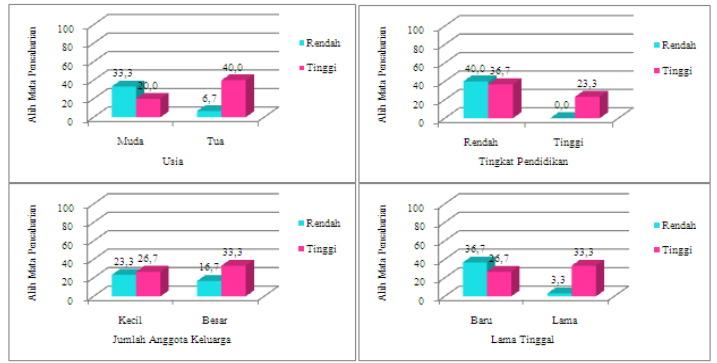

Sumber: Data primer diolah, 2012

Gambar 10. Persentase Hubungan antara Karakteristik Responden dengan Strategi Adaptasi Alih Mata Pencaharian di Desa Klaces. Kecamata Kampung Laut, Kabupaten Cilacap, Provinsi Jawa Tengah Tahun

Hasil penelitian menunjukkan bahwa:

1. Usia memengaruhi pilihan strategi adaptasi alih mata pencaharian karena semakin tua usia maka kondisi fisiknya pun semakin lemah sehingga tidak mampu lagi melaut.

2. Jumlah anggota keluarga memengaruhi pilihan strategi adaptasi alih mata pencaharian karena semakin besar keluarganya maka masyarakat cenderung mengganti pekerjaan utama menjadi petani, dimana pekerjaan sebagai petani lebih mudah dalam menyertakan keluarga untuk bekerja dibandingkan nelayan.

3. Masyarakat yang telah lama tinggal di Desa Klaces cenderung melakukan strategi adaptasi alih mata pencaharian karena beberapa responden lebih memilih untuk mencoba pekerjaan baru daripada bertahan dengan pekerjaan lama yang dianggap tidak menguntungkan lagi.

4. Hal yang umumnya memengaruhi pilihan strategi adaptasi alih mata pencaharian adalah kondisi pendapatan dan/atau kondisi diri, yang mencakup besarnya pendapatan dan kemampuan fisik.

\section{Hubungan Karakteristik Responden dengan Strategi Adaptasi Lainnya}

Hasil analisis data menunjukkan bahwa karakteristik tingkat pendidikan, jumlah anggota keluarga, dan lama tinggal yang berbeda tidak berhubungan dengan pilihan strategi adaptasi lainnya. Perbedaan kategori tingkat pendidikan, jumlah anggota keluarga dan lama tinggal tidak memengaruhi rendah atau tingginya strategi adaptasi lainnya. Namun, karakteristik usia berhubungan dengan pilihan strategi adaptasi lainnya. Semakin tua usia maka responden cenderung tidak melakukan strategi adaptasi lainnya. Gambar 11 menyajikan data mengenai persentase hubungan antara karakteristik responden dengan strategi adaptasi lainnya. 


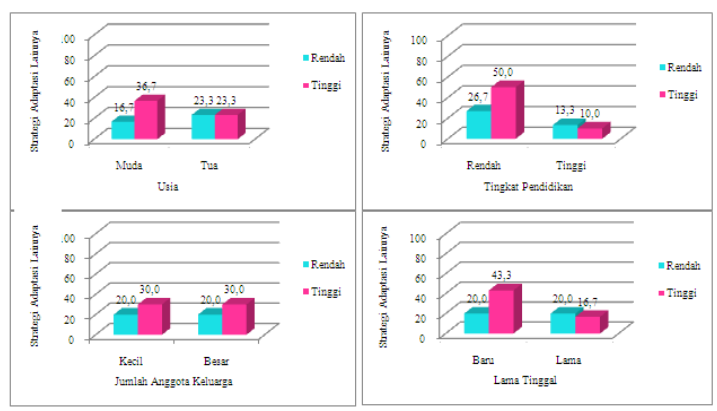

Sumber: Data primer diolah, 2012

Gambar 11. Persentase Hubungan antara Karakteristik Responden dengan Strategi Adaptasi Lainnya di Desa Klaces, Kecamatan Kampung Laut, Kabupaten Cilacap. Provinsi Jawa Tengah Tahun 2012

Hasil penelitian menunjukkan bahwa:

1. Usia memengaruhi pilihan strategi adaptasi lainnya karena sebagian besar masyarakat berusia tua diketahui bahwa tidak lagi memiliki aset yang bisa dijual/digadaikan atau jika memiliki berbagai aset yang bisa dijual/digadaikan, kondisi ekonomi masyarakat tersebut tinggi sehingga tidak perlu lagi melakukan strategi adaptasi lainnya. Selain itu, kondisi fisik masyarakat yang berusia tua tidak lagi mampu untuk mencari dan mengumpulkan hasil hutan yang ada.

2. Hal yang umumnya memengaruhi pilihan strategi adaptasi lainnya adalah situasi dan kondisi di saat mengalami kesulitan. Jika memungkinkan untuk melakukan strategi adaptasi yang telah disebutkan sebelumnya, maka masyarakat tidak akan melakukan strategi adaptasi lainnya, tetapi jika tidak ada strategi adaptasi yang mungkin untuk dilakukan, maka pilihan terakhir adalah dengan melakukan strategi adaptasi lainnya.

\section{Analisis Hubungan Strategi Adaptasi Nelayan dengan Mobilitas Sosial Nelayan}

Terdapat enam variabel strategi adaptasi nelayan yang dianalisis hubungannya dengan mobilitas sosial nelayan, yaitu jejaring/hubungan sosial, pola nafkah ganda, mobilisasi peran keluarga, migrasi, alih mata pencaharian, dan strategi adaptasi lainnya. Analisis ini dilakukan untuk mengetahui apakah pilihan adaptasi yang berbeda berhubungan dengan mobilitas sosial. Mobilitas sosial tersebut meliputi mobilitas sosial intragenerasi dan mobilitas sosial antar-generasi.

\section{Hubungan Strategi Adaptasi dengan Tipe Mobilitas Sosial Intra-Generasi}

Hasil analisis data menunjukkan bahwa strategi adaptasi mobilisasi peran keluarga, migrasi, alih mata pencaharian, dan strategi adaptasi lainnya tidak berhubungan dengan tipe mobilitas sosial intra-generasi. Perbedaan rendah atau tingginya strategi adaptasi tersebut tidak memengaruhi sebaran tipe mobilitas sosial intra-generasi. Namun, strategi adaptasi jejaring/hubungan sosial dan pola nafkah ganda berhubungan dengan tipe mobilitas sosial intra-generasi. Semakin tinggi strategi adaptasi jejaring/hubungan sosial dan pola nafkah ganda maka responden cenderung tidak mengalami mobilitas sosial naik. Gambar 12 menyajikan data mengenai persentase hubungan antara strategi adaptasi dengan tipe mobilitas sosial intra-generasi.

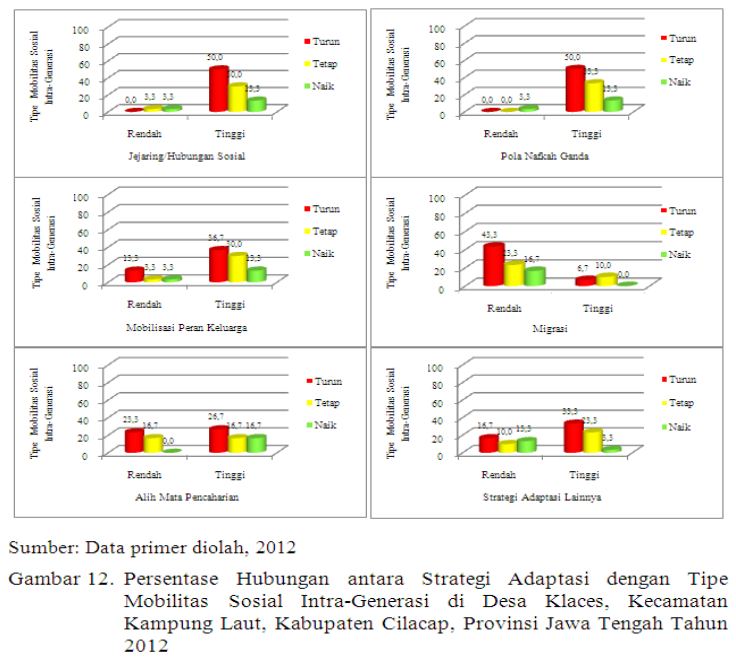

Hasil penelitian menunjukkan bahwa:

1. Strategi adaptasi jejaring/hubungan sosial berhubungan dengan tipe mobilitas sosial intragenerasi karena sebagian besar masyarakat yang melakukan strategi adaptasi jejaring/hubungan sosial merupakan masyarakat yang memiliki pekerjaan tergolong rendah pada lapisan stratifikasi sosial.

2. Strategi adaptasi pola nafkah ganda berhubungan dengan tipe mobilitas sosial intra-generasi karena masyarakat yang melakukan strategi adaptasi pola nafkah ganda sebagian besar merupakan masyarakat berpendidikan rendah sehingga masyarakat memiliki pekerjaan yang rendah juga sesuai pendidikannya.

3. Strategi adaptasi mobilisasi peran keluarga, migrasi, alih mata pencaharian, dan strategi adaptasi lainnya tidak berhubungan dengan tipe mobilitas sosial intra-generasi karena tidak ada pengaruh perbedaan pilihan dari strategi adaptasi tersebut terhadap sebaran tipe mobilitas sosial intra-generasi. Penyebabnya adalah sebagai berikut:

a. Masyarakat yang melakukan strategi adaptasi mobilisasi peran keluarga pada kenyataan tidak memengaruhi pekerjaan utama kepala keluarga. Strategi ini hanya memengaruhi keterlibatan anggota keluarga dalam meningkatkan pendapatan keluarga.

b. Masyarakat melakukan strategi adaptasi migrasi sebagai pekerjaan sampingan sehingga tidak dibandingkan dengan pekerjaan terdahulu (nelayan).

c. Fakta di lapangan membuktikan bahwa terjadi atau tidaknya alih mata pencaharian tetap 
mengakibatkan perubahan posisi masyarakat pada stratifikasi sosial. Adapun masyarakat yang tidak melakukan alih mata pencaharian adalah masyarakat yang saat ini bekerja sebagai nelayan madong. Sementara masyarakat yang melakukan alih mata pencaharian sebagian besar memiliki pekerjaan yang lebih rendah posisinya pada stratifikasi sosial dibandingkan pekerjaan terdahulu.

d. Masyarakat melakukan strategi adaptasi lainnya terlepas dari status pekerjaannya. Apapun pekerjaannya, saat mengalami kesulitan ekonomi dan tidak ada lagi strategi adaptasi yang bisa dipilih, maka masyarakat akan melakukan strategi adaptasi ini.

\section{Hubungan Strategi Adaptasi dengan Tipe Mobilitas Sosial Antar-Generasi}

Hasil analisis data menunjukkan bahwa strategi adaptasi jejaring/hubungan sosial, pola nafkah ganda, mobilisasi peran keluarga, migrasi, alih mata pencaharian, dan strategi adaptasi lainnya tidak berhubungan dengan tipe mobilitas sosial antar-generasi. Perbedaan rendah atau tingginya strategi adaptasi tersebut tidak memengaruhi sebaran tipe mobilitas sosial antar-generasi. Gambar 13 menyajikan data mengenai persentase hubungan antara strategi adaptasi dengan tipe mobilitas sosial antargenerasi.

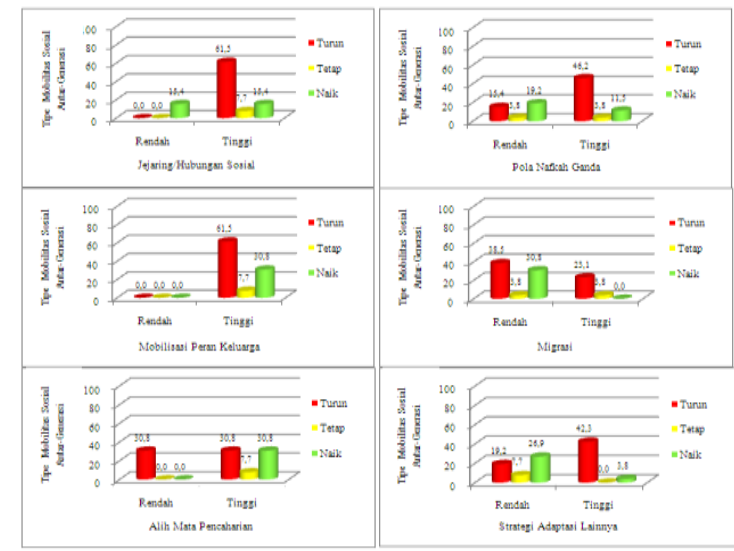

Sumber: Data primer diolah, 2012

Gambar 13. Persentase Hubungan antara Strategi Adaptasi dengan Tipe Mobilitas Sosial Antar-Generasi di Desa Klaces, Kecamata Kampung Laut, Kabupaten Cilacap, Provinsi Jawa Tengah Tahun 2012

Hasil penelitian menunjukkan bahwa mobilitas sosial antar-generasi hanya dipengaruhi oleh status pekerjaan anak yang dibandingkan dengan pekerjaan ayah terdahulu (nelayan). Berdasarkan hasil observasi diketahui bahwa strategi adaptasi mobilisasi peran keluarga merupakan tolak ukur terjadi atau tidaknya mobilitas sosial antar-generasi dalam suatu keluarga.

\section{PENUTUP}

\section{Kesimpulan}

Hasil penelitian menunjukkan bahwa perubahan ekologi di Desa Klaces diakibatkan oleh sedimentasi Daerah Aliran Sungai (DAS). Bentuk perubahan ekologi dapat dilihat dari semakin dangkalnya perairan, timbulnya daratan baru, semakin sempitnya luas perairan, semakin majunya garis pantai, terjadinya kerusakan mangrove, semakin kotor dan keruhnya perairan, serta terjadinya kerusakan daerah pemijahan biota laut. Adapun dampak sosial-ekonomi yang ditimbulkan oleh perubahan ekologi tersebut diantaranya adalah berubahnya bentuk rumah, tingginya kerugian ekonomi akibat banjir, berubahnya mata pencaharian, serta menurunnya produktivitas perikanan.

Kondisi-kondisi tersebut mengharuskan nelayan untuk dapat beradaptasi sebagai upaya mempertahankan kelangsungan hidupnya. Hasil penelitian menunjukkan bahwa strategi adaptasi yang dilakukan oleh responden berbeda-beda dan tidak hanya terpaku pada satu jenis strategi adaptasi saja. Responden mengkombinasikan berbagai jenis strategi adaptasi sesuai sumberdaya yang dimilikinya. Hasil survai di lokasi penelitian menunjukkan bahwa sebanyak 93,3 persen responden melakukan strategi adaptasi jejaring/hubungan sosial, 96,7 persen responden melakukan strategi adaptasi pola nafkah ganda, 80,0 persen responden melakukan strategi adaptasi mobilisasi peran keluarga, 16,7 persen responden melakukan strategi adaptasi migrasi, 60,0 persen responden melakukan strategi adaptasi alih mata pencaharian, dan 60,0 persen responden melakukan strategi adaptasi lainnya. Hasil penelitian ini menunjukkan bahwa strategi adaptasi pola nafkah ganda merupakan strategi adaptasi yang dominan dilakukan oleh responden.

Perubahan pekerjaan akibat strategi adaptasi yang dilakukan responden mengakibatkan perubahan stratifikasi sosial dalam masyarakat. Stratifikasi sosial inilah yang kemudian menunjukkan mobilitas sosial nelayan di Desa Klaces. Hasil penelitian menunjukkan bahwa mobilitas sosial yang terjadi di Desa Klaces meliputi mobilitas vertikal turun, mobilitas horizontal, dan mobilitas vertikal naik. Rincian mobilitas sosial intra-generasi yang dialami responden adalah 50,0 persen mengalami mobilitas vertikal turun, 33,3 persen mengalami mobilitas horizontal, dan 16,7 persen mengalami mobilitas vertikal naik. Sementara rincian mobilitas sosial antar-generasi yang dialami responden adalah 61,5 persen mengalami mobilitas vertikal turun, 7,7 persen mengalami mobilitas horizontal, dan 30,8 persen mengalami mobilitas vertikal naik. Hasil penelitian ini menunjukkan bahwa baik pada mobilitas sosial intra-generasi maupun antar-generasi, sebagian besar responden mengalami mobilitas vertikal turun.

Hasil analisis data menunjukkan bahwa karakteristik responden tidak selalu memengaruhi strategi adaptasi 
nelayan. Karakteristik responden yang memengaruhi strategi adaptasi nelayan adalah sebagai berikut:

1. Usia memengaruhi strategi adaptasi alih mata pencaharian dan strategi adaptasi lainnya. Semakin tua usia maka responden cenderung melakukan strategi adaptasi alih mata pencaharian dan semakin tua usia maka responden cenderung tidak melakukan strategi adaptasi lainnya.

2. Tingkat pendidikan memengaruhi strategi adaptasi pola nafkah ganda. Semakin tinggi pendidikan maka responden cenderung tidak melakukan strategi adaptasi pola nafkah ganda.

3. Jumlah anggota keluarga memengaruhi strategi adaptasi jejaring/hubungan sosial, pola nafkah ganda, mobilisasi peran keluarga, migrasi, dan alih mata pencaharian. Semakin besar jumlah anggota keluarga maka responden cenderung melakukan strategi adaptasi jejaring/hubungan sosial, pola nafkah ganda, mobilisasi peran keluarga, migrasi, dan alih mata pencaharian.

4. Lama tinggal memengaruhi pola nafkah ganda, dan alih mata pencaharian. Semakin lama tinggal maka responden cenderung tidak melakukan strategi adaptasi pola nafkah ganda dan semakin lama tinggal maka responden cenderung melakukan strategi adaptasi alih mata pencaharian.

Sementara karakteristik responden yang tidak memengaruhi strategi adaptasi nelayan adalah sebagai berikut:

1. Usia tidak memengaruhi strategi adaptasi jejaring/hubungan sosial, pola nafkah ganda, mobilisasi peran keluarga, dan migrasi.

2. Tingkat pendidikan tidak memengaruhi jejaring/hubungan sosial, mobilisasi peran keluarga, migrasi, alih mata pencaharian, dan strategi adaptasi lainnya.

3. Jumlah anggota keluarga tidak memengaruhi strategi adaptasi lainnya.

4. Lama tinggal tidak memengaruhi strategi adaptasi jejaring/hubungan sosial, mobilisasi peran keluarga, migrasi, dan strategi adaptasi lainnya.

Hasil analisis data juga menunjukkan bahwa strategi adaptasi nelayan tidak selalu memengaruhi mobilitas sosial nelayan. Strategi adaptasi yang memengaruhi mobilitas sosial nelayan adalah strategi adaptasi jejaring/hubungan sosial dan pola nafkah ganda yang memengaruhi tipe mobilitas sosial intra-generasi. Semakin tinggi strategi adaptasi jejaring/hubungan sosial dan pola nafkah ganda maka responden cenderung tidak mengalami mobilitas sosial naik. Sementara strategi adaptasi mobilisasi peran keluarga, migrasi, alih mata pencaharian, dan strategi adaptasi lainnya tidak memengaruhi tipe mobilitas sosial intra-generasi, serta seluruh strategi adaptasi nelayan tidak memengaruhi tipe mobilitas sosial antar-generasi.

\section{Saran}

Berdasarkan kesimpulan di atas ada beberapa saran dalam menghadapi perubahan ekologi di wilayah pesisir akibat sedimentasi Daerah Aliran Sungai (DAS), yaitu:

1. Pemerintah perlu meningkatkan pelaksanaan berbagai program yang mampu meningkatkan kualitas dan taraf hidup masyarakat pesisir, antara lain program kejar paket $\mathrm{A}, \mathrm{B}$, dan $\mathrm{C}$; program pemberian beasiswa kepada putra daerah; serta program PNPM Mandiri Perdesaan.

2. Pemerintah, akademisi, dan pihak swasta terkait perlu melakukan penyuluhan dan pelatihan bagi masyarakat mengenai cara-cara pengelolaan sumberdaya alam di sekitarnya sehingga masyarakat tetap dapat bertahan hidup dengan memaksimalkan pemanfaatan sumberdaya alam yang masih ada pasca sedimentasi DAS. Penyuluhan dan pelatihan yang dibutuhkan oleh masyarakat antara lain:

a. Bidang pertanian, perlu penyuluhan dan pelatihan mengenai cara-cara bertani di tanah hasil sedimentasi dan cara-cara pengolahan hasil panen yang disertai dengan praktik langsung oleh masyarakat setempat. Jika masyarakat bisa melakukan praktik pertanian di tanah hasil sedimentasi dan mengetahui cara-cara pengolahan hasil panennya dengan baik, maka diharapkan masyarakat bisa memperoleh hasil maksimal dari pertanian yang lebih baik dari sebelumnya.

b. Bidang pertambakan, perlu adanya penyuluhan dan pelatihan mengenai cara-cara bertambak yang disertai dengan praktik langsung oleh masyarakat setempat. Praktik tersebut harus didukung dengan pemberian modal oleh pemerintah atau pihak swasta terkait, agar masyarakat pesisir bisa mengembangkan sektor pertambakan yang menjadi salah satu potensi di wilayahnya.

c. Bidang wirausaha, perlu dilakukan penyuluhan dan pelatihan kepada masyarakat mengenai usaha-usaha rumah tangga (skala kecil atau disesuaikan dengan kondisi sosial-ekonomi masyarakat) dengan pemberian modal usaha serta pemantauan dan pembinaan rutin dari pemberi modal.

3. Pemerintah dan masyarakat perlu melakukan diversifikasi alat tangkap untuk meningkatkan hasil tangkapan, antara lain diversifikasi alat tangkap kepiting bagi nelayan penangkap kepiting di Desa Klaces (disesuaikan dengan kondisi alam di wilayah pesisir).

4. Pemerintah perlu meningkatkan kualitas dan kuantitas sarana dan prasarana umum di wilayah pesisir sehingga masyarakat tetap bertahan hidup di desanya tanpa melakukan migrasi ke daerah lain (terutama ke kota) yang selama ini dianggap lebih 
menjanjikan jika dilihat dari ketersediaan sarana dan prasarana umumnya.

5. Masyarakat yang memiliki pendidikan tinggi hendaknya tetap bersedia hidup dan menetap di desanya untuk membantu pemerintah dan masyarakat dalam meningkatkan kualitas dan taraf hidup masyarakat di wilayah pesisir.

\section{REFERENSI}

Arsyad S. 2010. Konservasi tanah dan air. Bogor [ID]: IPB Press. 472 hal.

[BPS] Badan Pusat Statistik. 2011. Statistik kelautan dan perikanan 2009. [Internet]. [dikutip 20 Desember 2011]. Jakarta [ID]: BPS dan Kementerian Kelautan dan Perikanan. 322 hal. Dapat diunduh dari: http://statistik.kkp.go.id/

Carner G. 1984. Survival, interdependence and competition among the philippine rural poor. Dalam: Korten DC dan Klauss R, editor. PeopleCentered Development.[Internet]. [dikutip $25 \mathrm{Mei}$ 2012]. Washington [AS]: Kumarian Press. Hal 133-143. Dapat diunduh dari: http://pdf.usaid.gov/pdf_docs/PNAAR213.pdf

Dahuri R, Rais J, Ginting SP, dan Sitepu MJ. 1996. Pengelolaan sumber daya wilayah pesisir dan lautan secara terpadu. Jakarta [ID]: Pradya Paramita. 305 hal.

Dharmawan AH. 2007. Antropologi budaya, sosiologi lingkungan dan ekologi politik. Dalam: Adiwibowo S, editor. Ekologi Manusia. Bogor [ID]: Fakultas Ekologi Manusia Press. Hal 17-42.

Iswandi RM. 2003. Analisis dampak pendangkalan Teluk Kendari terhadap aktivitas masyarakat dan strategi penanggulangannya. [disertasi]. Bogor [ID]: Institut Pertanian Bogor. 163 hal.

[KPSKSA] Kantor Pengelola Sumberdaya Kawasan Segara Anakan Kabupaten Cilacap. 2009. Data dan informasi Segara Anakan. Cilacap [ID]: KPSKSA Kabupaten Cilacap. 64 hal.

Kusnadi. 2000. Nelayan: strategi adaptasi dan jaringan sosial. Bandung [ID]: Humaniora Utama Press. 244 hal.

Mulyadi S. 2005. Ekonomi kelautan. Jakarta [ID]: Raja Grafindo Persada. 223 hal.

Patriana R. 2011. Pola adaptasi nelayan terhadap perubahan iklim (studi kasus nelayan Dusun Ciawitali, Desa Pamotan, Kecamatan Kalipucang, Kabupaten Ciamis, Jawa Barat). [skripsi]. Bogor [ID]: Institut Pertanian Bogor. 121 hal.

Saharuddin. 2007. Antropologi ekologi. Dalam: Adiwibowo S, editor. Ekologi Manusia. Bogor [ID]: Fakultas Ekologi Manusia Press. Hal 43-70.

Satria A. 2000. Modernisasi perikanan dan mobilitas sosial nelayan (studi kasus Kelurahan Krapyak Lor Kodya Pekalongan Jawa Tengah). [tesis]. Bogor [ID]: Institut Pertanian Bogor. 141 hal.

2001. Dinamika modernisasi perikanan formasi sosial dan mobilitas nelayan. Bandung [ID]: Humaniora Utama Press. 153 hal.
2002. Sosiologi masyarakat pesisir. Jakarta

[ID]: Pustaka Cidesindo.130 hal.

2009. Pesisir dan laut untuk rakyat. Bogor [ID]: IPB Press. 144 hal.

Soekanto S. 1990. Sosiologi: suatu pengantar. Jakarta [ID]: Raja Grafindo Persada. 456 hal.

Sorokin PA. 1959. Social and cultural mobility. London [IO]: Collier-Macmillan Ltd. 645 hal.

1962. Social stratification. Dalam: Talcot Parsons, Edward Shills, Kaspar P. Naegele, Jesse R Pits, editor. Theories of Society: Foundations of Modern Sociological Theory. London [IO]: The Free Press of Glencoe. 795 hal.

Stake RE. 2009. "Studi kasus," handbook of qualitative research. Dalam: Norman KD dan Yvonna SL, editor. Yogyakarta [ID]: Pustaka Pelajar. 643 hal.

Suripin. 2002. Pelestarian sumber daya tanah dan air. Yogyakarta [ID]: ANDI. 208 hal.

[UU] undang-undang Nomor 27 Tahun 2007 Tentang Pengelolaan Wilayah Pesisir dan Pulau-pulau Kecil.

Yunus L dan Dharmawan AH. 2005. Kerusakan hulu daerah aliran sungai citanduy dan akibatnya di hilir (studi penilaian ekonomi di sub DAS Citanduy hulu Jawa Barat dan sub DAS Segara Anakan Jawa Tengah). Bogor [ID]: Pusat Studi Pembangunan-Institut Pertanian Bogor. 66 hal.

Zanden JWV. 1990. Sociology: the core. New York [US]: McGraw-Hill. 432 hal. 